\title{
SECURITIZATION OF SEARCH AND RESCUE AT SEA: THE RESPONSE TO BOAT MIGRATION IN THE MEDITERRANEAN AND OFFSHORE AUSTRALIA
}

\author{
Daniel Ghezelbash*, Violeta Moreno-Lax**, Natalie Klein*** \\ AND BRIAN OPESKIN****
}

\begin{abstract}
This article compares the law and practice of the European Union and Australia in respect to the search and rescue (SAR) of boat migrants, concluding that the response to individuals in peril at sea in both jurisdictions is becoming increasingly securitized. This has led to the humanitarian purpose of SAR being compromised in the name of border security. Part I contrasts the unique challenge posed by SAR operations involving migrants and asylum seekers, as opposed to other people in distress at sea. Part II analyses the relevant international legal regime governing SAR activities and its operation among European States and in offshore Australia. Part III introduces the securitization framework as the explanatory paradigm for shifting State practice and its impact in Europe and Australia. It then examines the consequences of increasing securitization of SAR in both jurisdictions and identifies common trends, including an increase in militarization and criminalization, a lack of transparency and accountability, developments relating to disembarkation and non-refoulement, and challenges relating to cooperation and commodification.
\end{abstract}

Keywords: Human rights, Australia, boat migrant, criminalization, Europe, extraterritorialization, maritime migration, Mediterranean, offshore border control, refugee, search and rescue, securitization.

\section{A TALE OF TWO RESCUES}

In 1997, two competitors in the Vendee Globe round-the-world solo yachting race capsized in the Southern Ocean after encountering tumultuous seas and severe gales. The sailors - one a Frenchman (Thierry Dubois), the other an Englishman (Tony Bullimore)—were 2,500 km from Australian shores when they activated their distress beacons. A search and rescue (SAR) operation

* Senior Lecturer, Law School, Macquarie University, daniel.ghezelbash@mq.edu.au.

** Senior Lecturer, School of Law, Queen Mary, University of London, v.moreno-lax@qmul.ac.uk.

*** Professor, Law School, Macquarie University, natalie.klein@mq.edu.au.

**** Professor of Law and Associate Dean (Research), Faculty of Law, University of Technology Sydney, Brian.Opeskin@uts.edu.au.

The authors acknowledge the excellent research assistance provided by Rebekah Stevens. 
ensued, involving two ships from the Royal Australian Navy and six aircraft from the Royal Australian Air Force, with hundreds of defence and civilian personnel also pressed into service. ${ }^{1}$ In an operation estimated to have cost over AUD 6 million, ${ }^{2}$ the lone sailors were rescued after four days and brought to safety in Australia.

Contrast this with a situation that arose in the Mediterranean in 2009, when two boats carrying 154 migrants, mainly Sub-Saharan Africans, began to take on water. The MV Pinar, a Turkish cargo vessel passing nearby, was diverted to rescue the survivors, some $76 \mathrm{~km}$ from the Italian island of Lampedusa and 211 $\mathrm{km}$ from Malta. ${ }^{3}$ However, there was uncertainty as to where the rescuees should be landed. A four-day standoff resulted between Italy and Malta, as each alleged that the other State was responsible for accepting the migrants. ${ }^{4}$ Italy's claim was based on the location of the incident within Malta's SAR zone; while Malta's claim was based on the closer proximity of Italian territory. Against the backdrop of ongoing irregular maritime flows from North Africa to Europe, it was clear that neither country wanted to accept the rescuees. Eventually, Italy relented on humanitarian grounds and permitted the Pinar to make landfall in Sicily, but not before one migrant had died on board the rescue vessel and another had to be airlifted because of a medical emergency.

The differences between these scenarios are stark, but not because they pit a benign Antipodean attitude to those in peril at sea against a malign European one. Indeed, Australia was itself heavily criticized for its own Pinar-like incident when in 2001 it refused to accept 433 asylum seekers rescued by a Norwegian vessel (MV Tampa) in international waters, within Indonesia's SAR zone, but just $140 \mathrm{~km}$ from the Australian territory of Christmas Island. ${ }^{5}$

Although the Vendee Globe and Pinar events activate similar international legal obligations, they also highlight practical differences that arise from the number of persons in need of rescue; their nationality and migration status; their likelihood of claiming international protection as refugees; the antecedent history of rescues at sea; and the domestic political consequences of benevolence towards boat migrants. The application of overlapping legal regimes, together with uncertainties in the rights and obligations of affected

1 M Daly, 'A Race against Time and Ocean' The Age (Melbourne, 11 January 1997) 15.

2 F Ogilvie, 'Tony Bullimore Sets Sail Alone on another Extreme Challenge' $A B C$ (Online, 1 May 2007) <http://www.abc.net.au/worldtoday/content/2007/s1911366.htm>.

3 R Vassallo, 'Politics, Legal Wrangling at Heart of Malta-Italy Standoff', Malta Today (Online, 19 April 2009) <http://archive.maltatoday.com.mt/2009/04/19/t10.html>; 'Italy: Immigrants Land in Sicily after Rejection by Malta', Adnkronos International (Online, 20 April 2009) < http://www1.adnkronos.com/AKI/English/Security/?id=3.0.3233123625>.

4 N De Blouw, 'Drowning Policies: A Proposal to Modify the Dublin Agreement and Reduce Human Rights Abuses in the Mediterranean' (2010) 40 CaWIntlLJ 335; S Klepp, 'A Double Bind: Malta and the Rescue of Unwanted Migrants at Sea, a Legal Anthropological Perspective on the Humanitarian Law of the Sea' (2011) 23 IJRL 538, 547.

5 P Matthews, 'Australian Refugee Protection in the Wake of the Tampa' (2002) 96 AJIL 661. 
States and individuals, has created opportunities for disparate responses. ${ }^{6}$ As one author remarked, 'coastal States are more open to accept those less in need of refuge in the certain knowledge that they can easily be repatriated, whereas those most in need of refuge will be spurned as a potential burden'.

This article examines the shift that has occurred in the European Union (EU) and Australia from a fundamentally humanitarian mission of SAR to a complex, securitized response to boat migration. The result is a situation in which the humanitarian purpose of SAR has become compromised in the name of border security with ensuing consequences. On this basis, Part II examines the core humanitarian dimensions of SAR under international law generally and its operation within the EU and in Australia. Part III introduces the securitization framework and its ramifications for the shift in approaches to SAR in each region. It then analyses the consequences of increasing securitization of SAR in both jurisdictions. These include an increase in militarization, lack of transparency and accountability, developments relating to disembarkation and non-refoulement, criminalization, commodification, and impediments to effective cooperation. The article concludes with some recommendations and suggestions for future research. Throughout the article we use the term 'boat migrant' to refer to migrants and asylum seekers voyaging by sea. It is significant to note that the overwhelming majority of those travelling to Europe and Australia, during the time that approaches to SAR were revised, have been found to be refugees. ${ }^{8}$

\section{SHIFTING LEGAL REGIMES FOR SEARCH AND RESCUE AT SEA}

The international laws that regulate maritime search and rescue are today a large canvas of overlapping treaty regimes. The most important regimes, chronologically, are the International Convention for the Safety of Life at Sea 1974 (SOLAS Convention), ${ }^{9}$ the International Convention on Maritime Search

6 N Klein, 'A Case for Harmonizing Laws on Maritime Interceptions of Irregular Migrants' (2014) 63 ICLQ 787; V Moreno-Lax, 'Seeking Asylum in the Mediterranean: Against a Fragmentary Reading of EU Member States' Obligations Accruing at Sea' (2011) 23 IJRL 174.

7 R Barnes, 'Refugee Law at Sea' (2004) 53 ICLQ 47, 49.

8 In Australia, between 70 and 100 per cent of asylum seekers arriving by boat in recent years have been found to be refugees: J Phillips, 'Asylum Seekers and Refugee: What Are the Facts?' (2015) Australian Parliamentary Library Research Paper Series 2014-15, 9. In the EU, the top boat migrant nationalities (ie Syrian, Afghan, and Iraqi) are also the top nationalities of registered asylum seekers and recognized refugees in EU-28. Combine: EUROSTAT, Asylum Quarterly Report (15 March 2017) $<$ http://ec.europa.eu/eurostat/statistics-explained/index.php/Asylum_quarterly_report>; with IOM, Missing Migrants Project - Migration Flows: Europe <http://migration.iom.int/europe/>. Note also that '[t] he vast majority - more than $80 \%$ - of those who reached Europe by boat in 2015 came from those three countries': 'Why is EU Struggling with Migrants and Asylum?', BBC News (Online, 3 March 2016) <http://www.bbc.co.uk/news/world-europe-24583286>.

9 International Convention for the Safety of Life at Sea (adopted 1 November 1974, entered into force 25 May 1980) 1184 UNTS 278 (SOLAS Convention). 
and Rescue 1979 (SAR Convention), ${ }^{10}$ and the United Nations Convention on the Law of the Sea 1982 (UNCLOS). ${ }^{11}$ Each has garnered substantial acceptance by the international community - the SOLAS Convention presently has 162 parties; the SAR Convention has 107 parties; and UNCLOS has 168 parties. ${ }^{12}$ Australia is party to all three conventions. The EU and all its Member States are party to UNCLOS and are thus respectively responsible for matters over which each has competence under EU law-which excludes SAR in relation to the Union, as further discussed below. ${ }^{13}$ All EU Member States have ratified the SOLAS Convention, and all but three Member States are party to the SAR Convention. ${ }^{14}$ Gaps in the universal coverage of the conventions still leave scope for the operation of customary international law, ${ }^{15}$ which also recognizes a legal obligation to rescue a person in distress at sea. ${ }^{16}$

The Mediterranean has long been the locus for SAR activities in Europe, although the crisis is more widespread. ${ }^{17}$ In 2015 , the number of arrivals peaked, with more than a million persons reaching the EU by sea, and nearly 4,000 perishing en route. While the number of arrivals dropped to just over 356,000 the following year, the rate of dead and missing increased to more than $5,000 .{ }^{18}$ This is a significant proportion of the 7,763 total migrant deaths worldwide for the same period. ${ }^{19}$ It is only since the implementation of the

10 International Convention on Maritime Search and Rescue (adopted 27 April 1979, entered into force 22 June 1985) 1405 UNTS 119 (SAR Convention).

11 United Nations Convention on the Law of the Sea (adopted 10 December 1982, entered into force 16 November 1994) 1833 UNTS 3 (UNCLOS).

12 'Status of Multilateral Conventions and Instruments in respect of which the International Maritime Organization or its Secretary-General Performs Depositary or Other Functions' (International Maritime Organization, 10 October 2016) ('IMO Status of Ratifications') <http:// www.imo.org/en/About/Conventions/StatusOfConventions/Pages/Default.aspx>.

${ }_{13}$ Council Decision 98/392/EC of 23 March 1998 concerning the conclusion by the European Community of the United Nations Convention of 10 December 1982 on the Law of the Sea and the Agreement of 28 July 1994 relating to the implementation of Part XI thereof [1998] OJ L179/1.

${ }^{14}$ The three EU Member States which have not ratified the SAR Convention are Austria, the Czech Republic and Slovakia. It is important to note that all three are landlocked and hence have no responsibility over SAR regions: IMO Status of Ratifications (n 12).

15 RR Churchill and A Lowe, The Law of the Sea (3rd edn, Manchester University Press 1999) 7-12; D Rothwell and T Stephens, The International Law of the Sea (2nd edn, Hart 2016) 22-3.

16 DP O'Connell, The International Law of the Sea (Clarendon Press 1982) 813-14; G Goodwin-Gill and J McAdam, The Refugee in International Law (3rd edn, Clarendon Press 2007) 278; M Pallis, 'Obligations of States towards Asylum Seekers at Sea: Interactions and Conflicts between Legal Regimes’ (2002) 14 IJRL 329, 333-4.

17 For a review covering developments since the inception of Frontex, see V Moreno-Lax, Accessing Asylum in Europe (Oxford University Press 2017) ch 6.

${ }^{18}$ UNHCR, 'Refugees \& Migrants Sea Arrivals in Europe: Monthly Data Update' (Bureau for Europe, December 2016) $1<$ https://data2.unhcr.org/en/documents/download/53447>; UNHCR, 'Mediterranean: Dead and Missing at Sea: January 2015-31 December 2016' (2017) <https:// data2.unhcr.org/en/documents/download/53632>.

19 Missing Migrants Project, 'Latest Global Figures: Migrant Fatalities Worldwide' (International Organization for Migration (IOM) 2017) < https://missingmigrants.iom.int/latestglobal-figures $>$. 
so-called EU-Turkey 'deal' of March 2016 that the Aegean route has been sealed. ${ }^{20}$ Cooperation with the Libyan Coast Guard thereafter, ${ }^{21}$ combining SAR with anti-smuggling operations, ${ }^{22}$ has also translated in reduced crossings through the Central Mediterranean. ${ }^{23}$

Australia's experience of boat migration is modest when compared to Europe. A little over 60,000 people have arrived in Australia by boat without authorization since 2000. ${ }^{24}$ The number of arrivals peaked in 2013 at 20,587. ${ }^{25}$ The subsequent introduction of a suite of restrictive border control measures has reduced the number to close to zero. ${ }^{26} \mathrm{~A}$ small number of vessels continue to attempt the journey to Australia but are intercepted and deflected at sea, either to their point of departure, or to one of Australia's offshore regional processing facilities in Nauru or Papua New Guinea ('PNG'). ${ }^{27}$ Estimating the number of migrants who have died at sea while attempting to make the journey to Australia is a contentious issue, with claims that the government at times may have inflated the numbers in order to justify its harsh deterrence policies. ${ }^{28}$ There is no doubting, however, that there has been significant loss of life at sea, with one independent monitoring body estimating just over 1,900 deaths since January $2000 .{ }^{29}$

Although European States and Australia are bound by key international legal obligations associated with SAR, their respective experiences with boat migrants have triggered responses intended to enhance their border security. This Part highlights the central obligations associated with SAR but indicates a shift in State practice in the interpretation and application of these international norms. The first section sets out the humanitarian purpose underpinning the international legal regime in place for SAR, which binds

20 EU-Turkey Statement, EC Press Release 144/16 (8 March 2016) <http://www.consilium. europa.eu/en/press/press-releases/2016/03/18-eu-turkey-statement/>; Seventh Report on the Progress made in the implementation of the EU-Turkey Statement, COM(2017) 470.

21 Memorandum of Understanding of 2 February 2017 on Cooperation in the Fields of Development, the Fight against Illegal Immigration, Human Trafficking and Fuel Smuggling and on Reinforcing the Security of Borders between the State of Libya and the Italian Republic $<$ http://itra.esteri.it/vwPdf/wfrmRenderPdf.aspx?ID=50975>.

${ }^{22}$ For a critique, see V Moreno-Lax and M Giuffré, 'The Rise of Consensual Containment: From "Contactless Control” to "Contactless Responsibility” for Forced Migration Flows' in S Juss (ed), Research Handbook on International Refugee Law (Edward Elgar, forthcoming).

${ }^{23}$ On the delivery of the European Agenda on Migration, COM(2017) 558, 2.

24 Migrant Smuggling Working Group, 'Statistics relating to Migrant Smuggling in Australia' (University of Queensland, TC Beirne School of Law, 24 March 2017) <https://law.uq.edu.au/ research/our-research/migrant-smuggling-working-group/statistics-relating-migrant-smugglingaustralia $>$.

25 J Phillips, 'Boat Arrivals and Boat "Turnbacks" in Australia since 1976: A Quick Guide to the Statistics’ (2017) (Australian Parliamentary Library Research Paper Series 2016-17).

26 ibid. 27 See (n 210) and related discussion.

${ }^{28}$ G Nakhoul, Overboard: You Would Not Believe what Really Triggered Australia's Controversial Policy on Boat People (Dar Meera 2011).

29 Border Crossing Observatory, 'Australian Border Deaths Database' (March 2017) <http:// artsonline.monash.edu.au/thebordercrossingobservatory/publications/australian-border-deathsdatabase/>. 
EU Member States and Australia. It then assesses the European approach to SAR, noting the increasing role played by the EU via its external frontiers agency, the European Border and Coastguard ('the EU Coastguard', also known as 'Frontex'), in border management. ${ }^{30}$ The third section assesses the Australian approach to SAR, which demonstrates a conflation of humanitarian norms of SAR with border security imperatives.

\section{A. Humanitarian Dimensions of the International Legal Regime for SAR}

The foundations of SAR may be seen in early Judeo-Christian writings, ${ }^{31}$ and were expounded by the earliest scholars of international law. ${ }^{32}$ The current manifestation of this humanitarian obligation is the legal requirement enshrined in Article 98(1) of UNCLOS. This Article provides that every State shall require the master of a ship flying its flag to (a) assist any person found at sea in danger of being lost, and (b) proceed with all possible speed to the rescue of persons in distress. By its terms, the obligation falls on the flag State to require a master, through domestic legislation, to take action in specific circumstances. In practice, the obligation is discharged by individuals (masters) who may have to interrupt their commercial voyages to attend to those in need. The beneficiaries of the obligation are persons in 'danger' or 'distress'; and the nature of the obligation is to 'render assistance' and 'rescue'. However, the absence of definitions of these terms has left room for disputation, particularly as to when a rescue operation is required and when it is completed. ${ }^{33}$ The obligations are not absolute: a master is not required to seriously endanger his ship, crew or passengers; nor to do more than may 'reasonably be expected'.

In addition to the obligations that fall on flag States, coastal States have obligations that extend beyond the mere making of laws. By Article 98(2), coastal States must promote the establishment, operation and maintenance of

${ }^{30}$ Regulation (EU) 2016/1624 of 14 September 2016 on the European Border and Coast Guard [repealing Council Regulation (EC) No 2007/2004 ('Frontex Regulation' or 'FR'), Regulation (EC) No 863/2007 ('RABIT'), and Regulation (EU) No 1168/2011 ('Frontex Recast Regulation' or 'FRR'] [2016] OJ L251/1 ('EBCGR'); for analysis, see Moreno-Lax, Accessing Asylum (n 17).

31 M Rader, 'The "Good Samaritan" in Jewish Law' (2001) 22 JLegMed 375.

32 For example, de Vattel claimed that 'to give assistance in such extreme necessity is so essentially conformable to humanity, that the duty is seldom neglected by any nation that has received the slightest polish of civilisation': E de Vattel, The Law of Nations, Or, Principles of the Law of Nature, Applied to the Conduct and Affairs of Nations and Sovereigns, with Three Early Essays on the Origin and Nature of Natural Law and on Luxury (LF edn 1797) Bk II Ch I [5] <http://oll.libertyfund.org/titles/2246>.

33 For a discussion of the politics of interpretation, see T Gammeltoft-Hansen, 'The Perfect Storm: Sovereignty Games and the Law and Politics of Boat Migration' in V Moreno-Lax and E Papastavridis (eds), 'Boat Refugees' and Migrants at Sea: A Comprehensive Approach. Integrating Maritime Security with Human Rights (Brill 2016) 60, 66; Arguing for a wide construction of the term 'distress' see L Komp, 'The Duty to Assist Persons in Distress: An Alternative Source of Protection against the Return of Migrants and Asylum Seekers to the High Seas?' in Moreno-Lax and Papastavridis ibid 222. 
'an adequate and effective search and rescue service' regarding safety at sea, and must cooperate with neighbouring States where required. ${ }^{34}$ Under the SAR Convention, States are required to participate in the development of SAR services 'to ensure that assistance is rendered to any person in distress at sea', and they must also establish SAR regions by agreement with other States. ${ }^{35}$ Pursuant to this obligation, the world's oceans have been divided into multiple SAR regions, with responsibility assigned to proximate coastal States. Australia, for example, has a SAR region of some $53,000,000 \mathrm{~km}^{2}$, covering one-tenth of the world's surface, and bordering the SAR regions of ten other countries. ${ }^{36}$ In Europe, coastal States at both sides of the Mediterranean cover the entirety of the sea's extension-except for the waters close to Libya, which has never officially declared a SAR zone or deposited information about its SAR services with the International Maritime Organization (IMO). ${ }^{37}$

Under the SOLAS Convention, a State party is required to regulate the activities of all ships flying its flag regardless of where they sail, ${ }^{38}$ and to provide for the rescue of persons in distress at sea 'around its coasts', without limit as to distance or maritime zone. ${ }^{39}$ Yet despite this apparent breadth, there are long-standing gaps in treaty law that give 'some leeway for political expediency'. ${ }^{40}$ Notably, the Annex to the 1974 SOLAS Convention, as originally concluded, imposed an obligation on a master of a ship 'to proceed with all speed to the assistance of ... persons in distress'. ${ }^{41}$ The beneficiaries of the obligation are persons in 'distress' (not danger) on a ship or survival craft, and the obligation is limited to giving assistance (not rescue). Like Article 98(a) of UNCLOS, the obligation is not absolute: a master's obligation arises only

34 The SOLAS Convention contains a provision akin to art 98(2) of UNCLOS. See SOLAS Convention, Annex, ch 5 reg 15(a). These arrangements are to include maritime safety facilities adequate for the location and rescue of such persons.

35 SAR Convention, Annex, [2.1.1], [2.1.4].

36 Australian Maritime Safety Authority, 'Australia's Search and Rescue Region' (Australian Government) < https://www.amsa.gov.au/search-and-rescue/australias-search-and-rescue-system/ australia-srr/index.asp $>$.

37 For a map of the SAR zones, see European Political Strategy Centre (EPSC), Irregular Migration via the Mediterranean: From Emergency Responses to Systemic Solutions, Issue 22 (February 2017) <https://ec.europa.eu/epsc/publications/strategic-notes/irregular-migrationcentral-mediterranean_en>; see also S Trevisanut, 'Search and Rescue Operations in the Mediterranean: Factor of Cooperation or Conflict?' (2010) 25 IJMCL 523, Annexes I-II.

38 SOLAS Convention, art II.

39 SOLAS Convention, Annex, ch 5 reg 15(a); Pallis (n 16) 335. Note, however, that SOLAS generally does not apply to public vessels such as warships and coastguard vessels participating in operations described in this article: SOLAS Convention, reg 3(a)(i).

${ }^{40}$ M Pugh, 'Drowning Not Waving: Boat People and Humanitarianism at Sea (2004) 17 JRS 50, 60; see also V Moreno-Lax, The Interdiction of Asylum Seekers at Sea: Law and (Mal)practice in Europe and Australia, Kaldor Centre Policy Brief No 4 (May 2017).

41 SOLAS Convention, Annex, ch 5 reg 10(a); Strictly speaking, however, a State's international legal obligations arise from the requirement in art 1(b) to promulgate all laws necessary to give full and complete effect to the instrument and its Annex. 
upon receiving a distress signal, and does not extend to giving assistance considered to be unreasonable or unnecessary. ${ }^{42}$

A key obligation in place under the SAR Convention since its inception in 1979 is that States must ensure that assistance is provided to any person in distress at sea 'regardless of the nationality status of such a person or the circumstances in which that person is found'. ${ }^{43}$ The 1998 revisions to the SAR Convention also contain definitions of 'search' and 'rescue'. 44 'Search' is an operation to locate persons in distress, and 'rescue' is an operation 'to retrieve persons in distress, provide for their initial medical or other needs, and deliver them to a place of safety'. A 'place of safety', however, is not defined, and it is clear from other provisions that disembarkation lies in the discretion of the coastal State. ${ }^{45}$

Concerns about the definition of distress as well as ambiguity about when rescue is completed prompted a dialogue between States and international organizations to provide greater certainty for stakeholders. ${ }^{46}$ In 2004, the IMO issued Guidelines on the Treatment of Persons Rescued at Sea (IMO Guidelines $)^{47}$ and amended the SOLAS Convention, with operative effect from $2006 .{ }^{48}$ The treaty amendments clarify the master's duty to provide assistance to persons in distress. That duty is now expressed to apply 'regardless of the nationality or status of such persons or the circumstances in which they are found', and requires the master to treat rescuees 'with humanity, within the capabilities and limitations of the ship'. Additional amendments address the issue of disembarkation, somewhat elliptically. State parties are now obliged to cooperate to ensure that masters are relieved of their obligations to assist 'with minimum further deviation from the ship's intended voyage'. The State responsible for search and rescue in that region is given 'primary responsibility' to ensure that assisted survivors are disembarked and delivered to a place of safety, taking into account the particular circumstances of the case. ${ }^{49}$ Some commentators have argued that the State coordinating the search and rescue has a residual obligation to allow disembarkation on its territory, if safe disembarkation elsewhere is not possible, but the issue is contentious. ${ }^{50}$

42 This does not mean that there are no other relevant obligations, eg, flowing from the right to life under human rights law, enjoining States to do everything within their power to preserve human life. On the extent of positive duties arising from the intersection between SAR and human rights law, see Komp (n 33). $\quad{ }^{43}$ SAR Convention, Annex, [2.1.10]. $\quad 44$ ibid [1.3].

45 ibid [3.1]; For example, States are required to cooperate for the purpose of allowing another State entry into its territorial sea to conduct SAR operations: see Barnes (n 7) 53.

46 For a history, see Barnes (n 7) 106-11.

47 IMO, 'Guidelines on the Treatment of Persons Rescued at Sea' (20 May 2014) Res MSC.167 (78) Annex 34.

48 IMO, 'Adoption of Amendments to the International Convention for the Safety of Life at Sea 1974 as Amended’ (20 May 2004) Res MSC.153(78) ch 5 reg 33.

49 E Papastavridis, The Interception of Vessels on the High Seas (Hart 2014) 297-300.

50 S Trevisanut, 'Is There a Right to be Rescued at Sea? A Constructive View' (2014) QuestIntlL, 7. cf Moreno-Lax (n 6). 
The Guidelines provide direction as to what 'a place of safety' is, but in terms that are themselves imprecise. ${ }^{51}$ A place of safety is a location where rescue operations are considered to terminate, and where the basic human needs of survivors to food, shelter, and medical treatment can be met. At first blush, this sounds like a location on land, but the Guidelines recognize that, at least ad interim, it may also be a location at sea, such as a rescue vessel, until the survivors are disembarked to their next destination. Yet the Guidelines also state that 'an assisting ship should not be considered a place of safety based solely on the fact that the survivors are no longer in immediate danger once aboard the ship'. ${ }^{52}$ Significantly, the Guidelines also stipulate that asylum seekers rescued at sea should not be disembarked in territories where they may face a well-founded fear of persecution. ${ }^{53}$ While the purport of these legal obligations is clear, there is sufficient obfuscation in the terms to allow for varied implementation by States.

\section{B. European Approach to 'Incidental SAR' and its Subsumption in Border Control}

The international SAR framework applies fully to EU Member States, which retain distinct responsibility for rescue at sea. Only Malta objected to the latest SAR revisions at the IMO - with that, however, not precluding the entry into force of the amendments. ${ }^{54}$ And the humanitarian dimension of SAR and its intertwining with human rights obligations has, moreover, been forcefully recognized by the European Court of Human Rights in its Hirsi judgment. ${ }^{55}$

Yet, even with these core obligations falling on individual Member States, the EU has moved to a central position in managing SAR, because of the perceived implications for border security. ${ }^{56}$ Border control and SAR activity have (operationally) merged, with the former gaining (practical) pre-eminence over the latter - in line with the allocation of powers in the EU Treaties. ${ }^{57}$ Indeed, 'maritime search and rescue and disembarkation are the competence

51 M Ratcovich, "The Concept of "Place of Safety": Yet Another Self-Contained Maritime Rule or a Sustainable Solution to the Ever Controversial Question of Where to Disembark Migrants Rescued at Sea?' (2015) 33 AustYBIL 81. $\quad 52$ IMO, Res MSC.167(78), [6.12]-[6.18].

53 IMO, Res MSC.167(78), [6.17].

54 IMO Status of Ratifications (n 12). Malta's objection means that it is not bound by the amendments.

55 ECtHR, Hirsi Jamaa v Italy, App 27765/09 (23 February 2012). For analysis, see J Coppens, 'The Law of the Sea and Human Rights in the Hirsi Jamaa and Others $v$ Italy Judgment of the European Court of Human Rights' in Y Haeck and E Brems (eds), Human Rights and Civil Liberties in the 21st Century (Springer 2014) 179.

56 See V Moreno-Lax, 'The EU Humanitarian Border and the Securitization of Human Rights: The "Rescue-through-Interdiction/Rescue-without-Protection" Paradigm' JComMarSt (forthcoming).

57 Consolidated version of the Treaty on the Functioning of the European Union [2012] OJ C326/01, art 77 . 
of the Member States [not Frontex or the EU]' ${ }^{58}$ The main function of the EU Coastguard is to coordinate operational cooperation between the Member States so as to reinforce the monitoring of the common external frontiers, ${ }^{59}$ with 'saving the lives of migrants' arising as a desirable by-product of maritime intervention. ${ }^{60}$

SAR has been demoted to a second plane also due to the division of labour regarding the launching and running of joint operations. Although the EU Coastguard is supposedly just a facilitator of operational cooperation, it plays a leading role in initiating and approving joint activities, and in their planning, deployment, and strategic evaluation. This blurs the lines of responsibility between it and the Member States and creates uncertainty regarding attribution of conduct that may violate human rights. ${ }^{61}$ Their mandates are increasingly intermingled — although Member States remain 'in principle' responsible for carrying out border controls (and are exclusively competent to exercise force), the EU Coastguard enables efficient controls on the ground through intelligence provision, tactical coordination, and operational funding. A co-dependency emerges between the EU Coastguard and the Member States, with the former translating the ambitions of the latter into operational detail - the whole focus thus remaining on border security, rather than on SAR at sea.

Joint missions may be launched at the request of a Member State, evaluated and 'approved' by the EU Coastguard. ${ }^{62}$ Article 15(4) of the Coastguard Regulation speaks of its faculty to 'recommend' to Member States the launch of joint operations or rapid border interventions. ${ }^{63}$ But in relation to maritime operations, it appears that search and rescue per se cannot constitute the overarching objective of a joint mission. Although 'some situations may involve humanitarian emergencies and rescue at sea', ${ }^{64}$ border surveillance

58 Council of the EU, Doc 14612/13 (10 October 2013) $2<$ http://www.statewatch.org/news/ 2013/oct/eu-sea-surveillance-14612-13.pdf>.

59 EBCGR arts 1, 4, 8.

${ }^{60}$ European Border Surveillance System (EUROSUR) Regulation (EU) 1052/2013, [2013] OJ L295/11, arts 1-2. For commentary, see J Rijpma and M Vermeulen, 'EUROSUR: Saving Lives or Building Borders?’ (2015) 24 European Security 454.

${ }^{61}$ M Fernandez, 'The EU External Borders Policy and Frontex-Coordinated Operations at Sea: Who is in Charge?' in Moreno-Lax and Papastavridis (n 33) 381; M Fink, "A "Blind Spot" in the Framework of International Responsibility? Third Party Responsibility for Human Rights Violations: The Case of Frontex' in Gammeltoft-Hansen and Vedsted-Hansen (eds), Human Rights and the Dark Side of Globalisation (Routledge 2016) 272.

62 EBCGR art 15(1)-(3).

63 ibid; The more forceful wording originally proposed by the European Commission granting Frontex a 'right to intervene' has not been finally retained, but that does not detract from the fact that the Agency can anyway exert significant influence; see also J Rijpma, 'The Proposal for a European Border and Coast Guard: Evolution or Revolution in External Border Management?' (2016) European Parliament Study PE $556.934<$ http://www.europarl.europa.eu/thinktank/en/document. html?reference=IPOL_STU(2016)556934>.

${ }^{64}$ Regulation (EU) No 656/2014 of 15 May 2014 establishing rules for the surveillance of the external sea borders in the context of operational cooperation coordinated by Frontex, [2014] OJ L189/93 ('Maritime Surveillance Regulation' or 'MSR') recital 4. 
remains the primary goal. ${ }^{65}$ This follows ' $[t]$ he objective of Union policy in the field'. While operations may contribute 'to ensuring the protection and saving of lives', their ultimate aspiration remains 'to prevent unauthorised border crossings, to counter cross-border criminality and to apprehend ...those persons who have crossed the border in an irregular manner' ${ }^{66}$ This does not mean the Member States and the EU Coastguard free themselves of their SAR and human rights obligations, ${ }^{67}$ but it requires that surveillance 'be effective in preventing and discouraging persons from circumventing checks at border crossing points' ${ }^{68}$ The bias is thus towards control and security, not SAR. ${ }^{69}$

It therefore appears that it will only be ' $[d]$ uring a border surveillance operation at sea' that 'a situation may occur where it will be necessary to render assistance to persons found in distress ${ }^{70}$ - SAR is thus framed as incidental to the patrolling mission. With that in mind, operational plans must contemplate a series of additional details, 'in accordance with the applicable provisions of international instruments, governing [SAR] situations and ... the protection of [human] rights'. ${ }^{71}$ These include rules on the identification and communication of cases of uncertainty, alert and distress; modalities of disembarkation; and the contact details of national authorities competent to adopt adequate follow-up measures. ${ }^{72}$

In case persons are found to be in distress, Member States (not the EU Coastguard) 'shall observe their obligation to render assistance' and 'ensure that their participating units comply with that obligation'.$^{73}$ The EU Coastguard is not directly responsible for guaranteeing compliance with SAR obligations, but only to support EU norms by reinforcing, assessing, and coordinating the actions of Member States.

The 2014 Maritime Surveillance Regulation (MSR) provides, nonetheless, some guidance regarding SAR. In line with international obligations, it makes explicit that the nationality, status or circumstances in which the persons are found are irrelevant. Moreover, the existence of an explicit request for assistance is considered unnecessary. ${ }^{74}$ Other factors must also be taken into account for the determination of a SAR-relevant situation, including the seaworthiness of the vessel, the number and medical condition of persons on board, the availability of water, fuel and food supplies, the absence of qualified crew and equipment, as well as the weather and sea conditions. ${ }^{75}$ The presence of pregnant women, minors, and asylum seekers may be decisive, as the special needs of vulnerable persons must be

${ }^{65}$ MSR art 1, recitals 3 and 20, defining the 'scope of application'.

${ }^{66}$ MSR recital 1; see also Regulation (EU) No 2016/399 of 9 March 2016 on a Union Code on the rules governing the movement of persons across borders (Schengen Borders Code), [2016] OJ L77/1 ('SBC') art 13. ${ }^{67}$ MSR arts 4(7), 9(1) and recitals 8-10. ${ }_{68}^{6}$ MSR recital 1.

69 This was also the case under the predecessor of the MSR. See V Moreno-Lax, 'The EU Regime on Interdiction, Search and Rescue, and Disembarkation: The Frontex Guidelines for Intervention at Sea' (2010) 25 IJMCL 621.

71 MSR recital 15.
74 MSR art 9(1). 
'addressed' throughout the operation. ${ }^{76}$ In such circumstances, participating units must transmit all the relevant details to the SAR Centre responsible for the SAR zone concerned and put themselves at its disposal. ${ }^{77}$ Pending instructions, they must take all the necessary safety measures, avoiding any action 'that might aggravate the situation or increase the chances of injury or loss of life', even if the persons on board refuse to accept assistance. ${ }^{78}$ So, at the end of the day, EU law adds an extra layer of specification to the definition of 'distress' on top of the 2004 IMO amendments, complementing the international regime - if only in this incidental manner that subordinates the relevance of SAR to border security operations, arguably in disconformity with the humanitarian spirit of maritime conventions and 'elementary considerations of humanity' in customary law. ${ }^{79}$

Triton offers a key example of one recent Frontex/EU Coastguardcoordinated operation in the Mediterranean following this pattern of relegated SAR action. ${ }^{80}$ It was launched as a replacement to the Italian (humanitarian/ military) Mare Nostrum operation, which rescued more than 130,000 persons between October 2013 and October 2014, ${ }^{81}$ but with a much less ambitious remit. ${ }^{82}$ While Mare Nostrum had a proactive SAR component ${ }^{83}$-and was partly discontinued precisely because of its perceived 'magnet' effect on boat arrivals ${ }^{84}$ _for Triton, 'the focus $\ldots$ is primarily border management'. ${ }^{85}$ As the European Commission confirmed, 'Frontex is neither a search and rescue

${ }^{76}$ MSR art 4(4). $\quad{ }_{77}^{77}$ MSR art 9(2)(a). $\quad{ }^{78}$ MSR arts 3, 9(2)(g), 9(2)(h).

79 Corfu Channel Case (United Kingdom v Albania), [1949] ICJ Rep 4, para 22. See also MV Saiga (No. 2) (St. Vincent v Guinea), [1999] ITLOS Rep 10, 120 ILR 143, para 55; and Juno Trader, [2004] ITLOS Rep 17, 128 ILR 267, para 77.

${ }^{80}$ Frontex, 'Frontex Launches Joint Operation Triton' (Frontex Press Release, 31 October 2014) $<$ http://frontex.europa.eu/news/frontex-launches-joint-operation-triton-JSYpL7>; see also Frontex, 'How does Frontex Joint Operation Triton Support Search and Rescue Operations?' $<$ http://ec. europa.eu/dgs/home-affairs/what-we-do/policies/european-agenda-migration/backgroundinformation/docs/frontex_triton_factsheet_en.pdf>.

${ }^{81}$ M Militare, 'Mare Nostrum Operation' (Ministero Della Difesa) $<\mathrm{http}: / /$ www.marina.difesa. it/EN/operations/Pagine/MareNostrum.aspx $>$. For a critique, see P Cuttitta, From the Cap Anamur to Mare Nostrum: Humanitarianism and Migration Controls at the EU's Maritime Borders, CLEER Working Papers 2014/7.

${ }^{82}$ European Council on Refugees and Exiles (ECRE), 'Mare Nostrum to End - New Frontex Operation Will Not Ensure Rescue of Migrants in International Waters' (ECRE 10 October 2014) < https://www.ecre.org/operation-mare-nostrum-to-end-frontex-triton-operation-will-notensure-rescue-at-sea-of-migrants-in-international-waters/>; both the budget and operational area were smaller, covering only 30 miles off the Italian coasts with a EUR 3 million monthly allocation (a third of Mare Nostrum's).

${ }^{83}$ See L Davies and A Neslen, 'Italy: End of Ongoing Sea Rescue Mission "Puts Thousands at Risk"' The Guardian (Online, 31 October 2014) <http://www.theguardian.com/world/2014/oct/31/ italy-sea-mission-thousands-risk $>$.

${ }^{84}$ N Farrell, 'Italy is Killing Refugees with Kindness: The "Mare Nostrum" Policy has Acted as a Magnet for Boat People' The Spectator (Online, 6 September 2014).

${ }^{85}$ Frontex, 'Frontex launches call for participation in JO Triton' (Frontex Press Release, 26 September 2014). 
body nor does it take up the functions of a Rescue Coordination Centre' ${ }^{86}$ Its role is merely to 'assist Member States to fulfil their obligations under international maritime law to render assistance to persons in distress' ${ }^{87}$ As such, it was in fact considered that Triton would 'not replace or substitute Italian obligations', 88 even if Mare Nostrum had been dismantled.

In May 2015, the revised operational plan of what has become Triton Plus was put forward to help Frontex 'fulfil its dual role of coordinating operational border support to Member States under pressure, and helping to save the lives of migrants at sea'. ${ }^{89}$ Yet, Frontex's Executive Director has insisted that saving migrants' lives 'shouldn't be' the priority for patrols because this lies beyond the Agency's legal mandate. ${ }^{90}$ The framing of SAR as an incident of frontier control is thus confirmed in the EU's current approach to boat migration across the Mediterranean, distilling a securitized understanding thereof, with the foremost concern being border management rather than the protection of life at sea.

\section{Offshore Australia: Increasing Conflation of SAR with Border Security}

The Australian government has been even bolder in its attempts at subsuming SAR under border control operations. In fact, there appears to have been a deliberate attempt to conflate the two, in order to expand the government's power to intercept, board and divert asylum seekers and migrants attempting to reach Australia by sea-challenging the applicable law of the sea rules on jurisdictional zones delimiting interdiction powers, ${ }^{91}$ and human rights law. While, on paper, the rules governing SAR activities are distinct to those that govern security-related interdiction activities, in practice, the line between the two regimes is purposely distorted.

The Rescue Coordination Centre, within the Australian Maritime Safety Authority (AMSA), ${ }^{92}$ is the agency designated with the task of coordinating

\footnotetext{
${ }^{86}$ European Commission, 'Frontex Joint Operation "Triton"- Concerted Efforts to Manage Migration in the Central Mediterranean' (Memo, 7 October 2014) <http://europa.eu/rapid/pressrelease_MEMO-14-566_en.htm>. 87 ibid (emphasis added).

88 ibid. On this point, see S Carrera and L den Hertog, 'Whose Mare? Rule of Law Challenges in the Field of European Border Surveillance in the Mediterranean' (CEPS 27 January 2015) <https:// www.ceps.eu/publications/whose-mare-rule-law-challenges-field-european-border-surveillancemediterranean $>$.

89 ibid (emphasis added); see also Frontex, 'Frontex Expands Its Joint Operation Triton' (Frontex Press Release, 26 May 2015) <http://frontex.europa.eu/news/frontex-expands-its-jointoperation-triton-udpbHP>.

90 'EU Borders Chief Says Saving Migrants' Lives "Shouldn't be Priority" for Patrols', The Guardian (Online, 22 April 2015) < https://www.theguardian.com/world/2015/apr/22/eu-borderschief-says-saving-migrants-lives-cannot-be-priority-for-patrols $>$.

91 For a detailed analysis of these jurisdictional zones and respective powers exercisable in each, see Churchill and Lowe (n 15) 60-222; Rothwell and Stephens (n 15) 30-179; D Guilfoyle, Shipping Interdiction and the Law of the Sea (Cambridge University Press 2009) 7-20; Papastavridis (n 49) 259-307 (focusing on the scope of powers to interdict persons on the high seas).

92 Established by the Australian Maritime Safety Authority Act 1990 (Cth).
} 
Australia's SAR operations. The rules governing how SAR is to be planned and carried out are promulgated in the National Search and Rescue Manual. ${ }^{93}$ While the document contains extensive detail in relation to SAR procedures and techniques, it makes no specific reference to the meaning of a 'place of safety' or selecting a point of disembarkation (let alone in conformity with non-refoulement). There is some guidance in relation to the standard for 'distress', which is said to occur when a vessel requires 'immediate assistance' resulting from 'grave or imminent danger' 94 _ so, presumably, unseaworthiness alone, which is the typical characteristic of boat migrant vessels, will not per se trigger a SAR response on the part of Australia.

Security and border control related maritime interdiction activities are coordinated by Australia's Maritime Border Command (MBC). ${ }^{95}$ The government's maritime enforcement powers are set out in the Maritime Powers Act 2013 (Cth) ('MPA'). Where a vessel is suspected of violating any Australian law, including immigration laws, the Act authorizes the use of certain interdiction powers. These include boarding, obtaining information, searching, detaining, seizing and retaining things; and moving and detaining persons. ${ }^{96}$ The Act also makes it clear that authorization from a statutory officer for the exercise of maritime powers is not required where the exercise is to ensure the safety of the officers or any other person. ${ }^{97}$ At times, the Australian Government has also claimed that maritime interdiction operations are authorized under its non-statutory executive (or prerogative) power. ${ }^{98}$

By comparison to the EU experience, there are no publicly available rules of engagement, regulations, or protocols in relation to Australia's maritime enforcement activities. The only relevant publicly available resource is the Guide to Australian Maritime Security Arrangements (GAMSA). ${ }^{99}$ This document sets out stakeholder roles in relation to eight civil maritime security threats, one of which is irregular maritime arrivals.

In practice, it can be very difficult to distinguish which powers the government purports to be exercising when it intercepts and diverts irregular migrant vessels. Under current arrangements, AMSA's Rescue Coordination Centre is the first point of contact for both maritime safety and maritime

93 Australian National Search and Rescue Council, National Search and Rescue Manual (Australian Maritime Safety Authority 2017) <https://natsar.amsa.gov.au/documents/NATSARManual/2017AustralianNationalSARManual.pdf $>$.

94 ibid 80.

95 The Maritime Border Command was known as the Border Protection Command prior to July 2015: 'Maritime Border Command's History' (Department of Immigration and Border Protection) $<$ https://www.border.gov.au/australian-border-force-abf/protecting/maritime/command/history>.

96 MPA Pt 3.

97 MPA section 29.

98 See the government's arguments in Ruddock v Vadarlis (2001) 110 FCR 491 and CPCF [2015] HCA 1 (28 January 2015).

99 Australian Border Protection Command, Guide to Australian Maritime Security Arrangements (GAMSA) (Australian Government 2013) <https://www.border.gov.au/ AustralianBorderForce/Documents/GAMSA\%202013.pdf>. As it was published in 2013, the titles of a number of named agencies have since changed. This article refers to the current names of the relevant agencies and stakeholders. 
security incidents. Where the incident is of a security nature, the Rescue Coordination Centre informs the $\mathrm{MBC}$, which then assumes responsibility for providing the response. The $\mathrm{MBC}$ coordinates interdiction activities using Australian Defence Force (ADF) or Australian Border Force (ABF) vessels. ${ }^{100}$ In cases of SAR, the Rescue Coordination Centre coordinates vessels to carry out the rescue. These vessels could be commercial ships or vessels operated by any Commonwealth or State or territory agency. Given the fact that the ADF and ABF vessels are stationed in the regions most affected by boat migration, it is often one of these vessels that are deployed to carry out the SAR operation. ${ }^{101}$ It is also important to note that an operation that starts out as an interdiction could transform into a SAR operation and vice versa, with authority for coordination switching between AMSA and the MBC accordingly. ${ }^{102}$

The functions of SAR and maritime interdiction have been further conflated as a result of Operation Sovereign Borders, launched in late 2013. The militaryled initiative has the goal of stopping boats suspected of carrying irregular migrants from entering Australian territory. ${ }^{103}$ This is achieved by physically intercepting and deflecting their vessels. The entire operation is shrouded in secrecy, with the government adopting a policy of not commenting on 'operational matters' for security reasons. ${ }^{104}$ Given this secrecy, there is little information about how and where interdiction and push-back operations occur and whether the government purports to be acting under its SAR or interdiction powers.

The result is that it is difficult to assess whether Australia complies with its obligations under international law or, rather, whether it exploits SAR provisions to expand its interdiction authority beyond allocated jurisdictional zones. The final outcome - by contrast to the 'relegated' or 'incidental SAR'

100 The Australian Border Force was established on 1 July 2015 after the merger of the Australian Customs and Border Protection Service and some parts of Department of Immigration and Border Protection: 'Our History' (Department of Immigration and Border Protection) < https://www.border. gov.au/about/corporate/history>.

101 AMSA, Senate Budget Estimates Briefing: Search and Rescue Operations (May 2014), obtained pursuant to a request made under the Freedom of Information Act 1982 (Cth) by H Degan on 20 June 2014.

${ }^{102}$ Evidence to Senate Standing Committee on Legal and Constitutional Affairs, Parliament of Australia, Correspondence dated 14 April 2014, 4-8<https://interactive.guim.co.uk/australia/2014/ june/osb-timeline/docs/customs-osb.pdf $>$ (providing examples of where the vessels are stationed, and how operations change from SAR to interdiction and vice versa).

103 'The Coalition's Operation Sovereign Borders Policy' (Liberal Party of Australia and The Nationals July 2013) <http://sievx.com/articles/OSB/201307xxTheCoalitionsOSBPolicy.pdf>; Note that this is a cached version as the original policy document was removed from the Liberal and National Party websites at the start of the 2016 election campaign.

104 E Griffiths, 'Scott Morrison says Government Won't Reveal When Asylum Seekers Boats Turned Back' ABC News (Online, 24 September 2013) <www.abc.net.au/news/2013-09-23/ government-won27t-reveal-when-boats-turned-back/4975742>; see also (n 179) and related discussion. 
paradigm reigning in Europe - is a 'conflated SAR' model that confuses rescue at sea with border security objectives.

\section{THE EXPLANATORY PARADIGM: SECURITIZATION}

Although the international SAR regime has its own distinct requirements, processes, and institutions, the increasing linkage between this regime and migration control has begun to infuse SAR with similar characterizations and responses to those seen in relation to irregular migration and its portrayal as 'a threat'. ${ }^{105}$ The basis for the shifting approach, away from the core focus of humanitarian assistance, is the use of a 'securitization frame', which assists in understanding why States take certain actions in response to boat migration. ${ }^{106}$ Securitization is the process whereby actors with sufficient authority identify existential threats to the State, society, or other particular object, and seek to implement extraordinary measures in response to the putative threat. ${ }^{107}$

The arrival of boat migrants is considered to be a threat to the destination State in this scenario. ${ }^{108}$ The threat might be cast as a result of the unknown background of the individuals, who may be perceived to be existing or potential criminals or terrorists. ${ }^{109}$ But the threat may be perceived more broadly as somehow jeopardizing the existing lifestyles, economy or cultures of the destination State. ${ }^{110}$ The confluence (or subordination) of SAR with (or to) migration control results in boat migrants constituting a threat, irrespective of whether they were rescued from a situation of distress or have otherwise entered a country without authorization.

Within the securitization frame, the actors who characterize the threat must have authority to speak about security and an audience that is receptive to how that threat is constructed. ${ }^{111}$ In Australia, one of the main political parties came to power in 2013 with a platform that included the mantra of

105 D Bigo, 'Security and Immigration: Toward a Critique of the Governmentality of Unease' (2002) 27 Alternatives 63; see also J Huysmans, 'The European Union and the Securitization of Migration' (2000) 38 JComMarSt 751; G Lazaridis and K Wadia, The Securitization of Migration in the EU: Debates Since 9/11 (Palgrave McMillan 2015).

106 For an analysis of contemporary 'threats to maritime security' that have contributed to increased securitization, see Papastavridis (n 49).

107 B Buzan et al., Security: A New Framework for Analysis (Lynne Rienner 1998) 32-3. For the sociological approach, cf T Balzacq (ed), Securitization Theory (Routledge 2011); and J Huysmans, The Politics of Insecurity (Routledge 2006).

108 Pugh (n 40) 52; see also SD Watson, 'Manufacturing Threats: Asylum Seekers as Threats or Refugees?' (2007) 3 JILIR 95, 101.

109 See LA Nessel, 'Externalised Borders and the Invisible Refugee' (2009) 40 ColumHumRtsLRev 625, 642 (referring to the US response to illegal boat arrivals from Haiti); see further in V Mitsilegas, 'Immigration Control in an Era of Globalization: Deflecting Foreigners, Weakening Citizens, Strengthening the State' (2012) 19 IndJGlobalLegalStudies 3, 12-17. 110 Pugh (n 40) 53.

${ }^{111}$ C Bueger, 'What is Maritime Security?' (2015) 53 MarPoly 159, 162. See also, generally, O Waever, 'Securitization and De-securitization' in RD Lipschutz (ed), On Security (Columbia University Press 1995) 46. 
'stop the boats'. ${ }^{112}$ In the EU, the European Coastguard was created with a mission 'to integrate national border security systems of Member States against all kinds of threats that could happen at or through the external border of the Member States'. ${ }^{113}$ As indicated above in relation to EU practice, boat migration has been one of the threats identified as requiring a border security response.

In implementing responses to a threat, a securitization frame may allow for drastic or atypical responses that prioritize ameliorating the security concerns. One example is seen in UN Security Council Resolution 2240 (2015), in which the Security Council authorizes inspection of vessels on the high seas off the coast of Libya that are reasonably suspected of migrant smuggling or human trafficking. ${ }^{114}$ In making this decision, ${ }^{115}$ the Security Council acted under Chapter VII of the UN Charter, which concerns threats to the peace, breaches of the peace, and acts of aggression. ${ }^{116}$ Despite the fact that a large number of deaths occurring during sea voyages across the Mediterranean have been attributed to unseaworthiness of the vessels, and hence might attract a response under the SAR regime, the Resolution focuses on the securitized perspective of people smuggling and human trafficking. The only mention of SAR is in the preambular paragraphs, where the Security Council recalls the existence of the SAR Convention, but, then again, frames loss of life at sea as a 'threat to international peace and security'.

The increasing conflation of SAR with migration control (as in Australia), or the subordination of the SAR regime to migration control rules and processes (as in the EU), is highly problematic. The securitization of SAR runs the risk of setting a crisis tone and prompting short-term responses that emphasize State security. ${ }^{117}$ As discussed further below, the practice of the EU and Australia presents compelling examples of securitizing SAR in the context of boat migration, which has distorted the primary humanitarian object of the regime. In both settings, although there is rhetoric in relation to saving lives at sea, the commitment to human rights obligations is lacking in reality, once effective control is being exercised over boat migrants. ${ }^{118}$ Instead, legal frameworks,

112 T Abbott, 'Address to the 2013 Federal Coalition Campaign Launch' (Brisbane, 25 August $2013)<$ http://parlinfo.aph.gov.au/parlInfo/search/display/display.w3p; query=Id\%3A\%22library\% 2Fpartypol\%2F2686857\%22>. $\quad{ }^{113}$ Nessel (n 109) 655.

114 UNSC Res 2240 (9 October 2015) UN Doc S/RES/2240, renewed by UNSC Res 2312 (6 October 2016) UN Doc S/RES/2312, para 7. See (n 134) and related discussion in Part III.A.

115 A decision of the Security Council adopted under the UN Charter is binding on all UN member States and trumps other international obligations: UN Charter art 25 and art 103.

116 UN Charter art 39.

117 See GS Goodwin-Gill, 'Setting the Scene: Refugees, Asylum Seekers, and Migrants at Sea the Need for a Long-Term, Protection-Centred Vision' in Moreno-Lax and Papastavridis (n 33) 17. Further on this point, see J Jeandesboz and P Pallister-Wilkins, 'Crisis, Enforcement and Control at the EU Borders' in A Lindley (ed), Crisis and Migration (Routledge 2014) 115; and J Jeandesboz and P Pallister-Wilkins, 'Crisis, Routine, Consolidation: The Politics of the Mediterranean Migration Crisis' (2016) 21 Mediterranean Politics 316.

${ }_{118}$ Moreno-Lax (n 56) and references therein; see also E Guild, C Costello and V Moreno-Lax, 'Implementation of the 2015 Council Decisions Establishing Provisional Measures in the Area of International Protection for the Benefit of Italy and Greece' (2017) European Parliament Study PE 
government institutions, and actual practices indicate an emphasis on border control and hence national security that overshadows - if not altogether sidelines - SAR in the context of boat migration.

Against this background, this Part explores the commonalities that exist between European and Australian experiences and the consequences of securitization. Specifically, it addresses the increasing militarization in SAR responses, the difficulties arising from differing interpretations of relevant legal terms, the lack of transparency and accountability, which compound the first two trends, the moves towards criminalizing humanitarian assistance, and the impediments to effective cooperation around SAR.

\section{A. Militarization}

The response to boat migration in both the EU and Australia is now marked by a trend towards increasing militarization of on-water responses to migrant vessels. Australia's Operation Sovereign Borders is a military-led initiative that operates under the command of an Army General. ${ }^{119}$ The Maritime Border Command tasked with coordinating maritime interdiction activities, while technically a civil maritime security authority, is commanded by a Rear Admiral seconded from Defence, who is responsible for coordinating assets and personnel from both the Australian Border Force (ABF) and Australian Defence Force (ADF). The ADF's contribution to Operation Sovereign Borders is codenamed Operation RESOLUTE. ${ }^{120}$ It involves the deployment of up to 800 ADF personnel at sea, in the air and on land, who work alongside personnel from the ABF. ${ }^{121}$ Resources allocated to the operation include Air Force AP-3C Orion maritime patrol aircraft, Navy Armidale Class Patrol Boats, and two Navy Major Fleet Units. ${ }^{122}$

In July 2017, the Department of Immigration and Border Protection confirmed that Australia had intercepted and turned back 30 boats carrying a total of 765 asylum seekers since the commencement of Operation Sovereign Borders. ${ }^{123}$ Details about individual operations were not provided. Media reports indicate that the majority of these incidents involved interdicting Indonesian vessels carrying boat migrants and returning them to the edge of

583.132; E Poptcheva, 'EU Legal Framework on Asylum and Irregular Immigration "On Arrival": State of Play' (2015) European Parliament Study PE 551.333.

119 It is currently under the command of Air Vice-Marshal Stephen Osborne: Peter Dutton MP, Minister for Immigration and Border Protection 'New Commander for Operation Sovereign Borders' (Media Release, 1 February 2017) <http://www.minister.border.gov.au/peterdutton/ Pages/New-Commander-for-Operation-Sovereign-Borders.aspx $>$.

${ }_{120}$ Department of Defence 'Border Protection News: Operation Resolute' (Australian Government) $<$ http://www.defence.gov.au/operations/BorderProtection/>. $\quad{ }_{121}$ ibid. 122 ibid.

${ }^{123}$ Evidence to Senate Legal and Constitutional Affairs Legislation Committee, Parliament of Australia, 7 July 2017 (Response to question taken on notice, BE17/042) <http://www.aph.gov. $\mathrm{au} /$ /media/Committees/legcon_ctte/estimates/bud_1718/DIBP/QoNs/BE17042.pdf $>$. 
Indonesian territorial waters, although more recent incidents have included turn-backs to Vietnam and Sri Lanka, rising high risks of refoulement. ${ }^{124}$ The precise locations of the interdictions are unclear. Some boat migrants have been towed back in their original vessels, while others have been transferred to custom-built orange lifeboats stocked with food, water, and medical supplies. ${ }^{125}$ It appears that the orange lifeboats have now been replaced by a fleet of Vietnamese-built wooden vessels resembling Asian fishing boats. ${ }^{126}$

The response in Europe has been similarly militarized - and heedless of nonrefoulement and other human rights obligations. The European Council's TenPoint Action Plan, adopted to implement the European Agenda on Migration at the outbreak of the 'migration crisis' in 2015, proposed the establishment of an EU-led naval force operation (EUNAVFOR) to operate in parallel to Frontexled activities. ${ }^{127}$ This was not intended to buttress SAR but rather 'to better contain [sic] the growing flows of illegal migration'. ${ }^{128}$

EUNAVFOR Med was launched shortly afterwards. ${ }^{129}$ The EU Commissioner for Home Affairs described the ultimate goal of the operation as the 'war on smugglers'. ${ }^{130}$ Several operational phases have been distinguished: the first for surveillance and assessment; the second for the search and seizure of migrant boats, including for the 'disposal of vessels ... preferably before use' and the apprehension of smugglers on high seas; a third phase taking place within Libyan jurisdiction; and a final phase for completion and handing over of responsibilities to the Libyan Coastguard, once sufficient progress will have been achieved.

The start-up phase, Operation Sophia, was launched in June 2015. ${ }^{131}$ Yet, to launch phases 2 and 3, it was acknowledged that the EU lacked jurisdiction, as

124 A Schloenhardt and C Craig, “"Turning Back the Boats”: Australia's Interdiction of Irregular Migrants at Sea' (2015) 27 IJRL 536, 548-58 (collating media reports in relation to Australian maritime interdiction activities up until 15 November 2014); Phillips (n 25) 4 (referencing reports of turnbacks to Sri Lanka and Vietnam).

125 Schloenhardt and Craig (n 124).

${ }^{126}$ B Doherty and H Davidson, 'Orange Lifeboats Used to Return Asylum Seekers to Be Replaced by "Fishing Boats"" The Guardian (Online, 4 March 2015) <http://www.theguardian. com/australia-news/2015/mar/05/orange-lifeboats-used-to-return-asylum-seekers-to-be-replacedby-fishing-boats $>$.

127 European Commission, 'Joint Foreign and Home Affairs Council: Ten Point Action Plan on Migration' (Press Release IP/15/4813, 20 April 2015) < http://europa.eu/rapid/press-release_IP-154813_en.htm>; European Agenda on Migration, COM(2015) 240 (13 May 2015).

${ }^{128}$ Council Conclusions (EUCO 22/15) of 26 June 2015, 1.

129 Council Decision (CFSP) 2015/778 of 18 May 2015 on a European Union military operation in the Southern Central Mediterranean (EUNAVFOR MED) [2015] OJ L122/31; Council Decision (CFSP) 2015/972 of 22 June 2015 launching the European Union military operation in the southern Central Mediterranean (EUNAVFOR MED) [2015] OJ L157/51.

130 'Europe Is Declaring War on Smugglers' CBS News (Online, 23 April 2015) <http://www. cbsnews.com/news/europe-response-migrant-boat-crisis-mediterranean-italy-rescue-drownings/>.

131 Council of the European Union, 'Council Launches EU Naval Operation to Disrupt Human Smugglers and Traffickers in the Mediterranean' (Press Release 482/15, 22 June 2015); Council of the European Union, 'Council Establishes EU Naval Operation to Disrupt Human Smugglers in the Mediterranean’ (Press Release 301/15, 18 May 2015); Council Decision 2015/972 (n 129). 
these entailed extraterritorial recourse to military force. ${ }^{132}$ Consequently, diplomatic representations were made at the bilateral level to persuade Libya and Tunisia, and at UN level to obtain the authorization of the Security Council. ${ }^{133}$ The latter resulted in UNSC Resolution 2240, on 9 October 2015, authorizing Member States 'to use all measures commensurate to the specific circumstances' to 'inspect', 'seize', and possibly 'dispose of' migrant vessels (including inflatable boats, rafts, and dinghies), so as to 'disrupt the organised criminal enterprises engaged in migrant smuggling and human trafficking', but only with respect to 'the situation of smuggling and trafficking on the high seas off the coast of Libya'. ${ }^{134}$

The fears expressed by the EU Defence Chiefs, when consulted on the design of the operation in documents filtered to the press by Wikileaks, are worth noting. They anticipated that EUNAVFOR Med was doomed to fail, and that it would further destabilize the region and divert migration to alternative (more dangerous) routes, thus paradoxically intensifying smuggling and trafficking activity. ${ }^{135}$ The clear evidence of spiralling fatality rates in the Mediterranean points, precisely, to the inadequacy of replacing SAR operations with law-enforcement or military missions unfit for purpose. 136

Nonetheless, EUNAVFOR Med's mandate has been extended and expanded to help implement an arms embargo on Libya and train the Libyan Navy and Coastguard, ${ }^{137}$ so that they can 'decrease irregular migration from Libya'. ${ }^{138}$ The long-term aim of this approach is to create a functioning Libyan capacity

\footnotetext{
${ }^{132}$ Council of the European Union, 'PMG Recommendations on the Draft Crisis Management Concept for a Possible CSDP Operation to Disrupt Human Smuggling Networks in the Southern Central Mediterranean, 8824/15, Brussels, 12 May 2015' (Wikileaks, 25 May 2015) <https:// wikileaks.org/eu-military-refugees/PMG/eu-military-refugee-plan-PMG.pdf $>$.

${ }^{133}$ F Mogherini, 'High Representative/Vice-President Federica Mogherini's Remarks' (UN Security Council, New York, 11 May 2015) <http://eeas.europa.eu/statements-eeas/2015/ 150511_03_en.htm>; see also UNSC Verbatim Record (11 May 2015) UN Doc S/PV/7439.

${ }_{134}$ UNSC Res 2240 (9 October 2015) UN Doc S/RES/2240 (emphasis added). For commentary, see E Papastavridis, EUNAVFORMed Operation Sophia: Fighting Smuggling of Migrants or Protecting Human Rights? CLEER Papers 2016/5, 139; and E Papastavridis, 'EUNAVFORMed Operation Sophia and the International Law of the Sea' (2016) 2 Maritime Safety and Security Law Journal 57.

${ }_{135}$ Council of the European Union (n 132).

136 W Spindler, 'Mediterranean Death Toll Soars to All-Time High' (UNHCR, 25 October 2016) $<$ http://www.unhcr.org/news/briefing/2016/10/580f1 d044/mediterranean-death-toll-soars-all-timehigh.html>. See also IOM, Missing Migrants Project (n 8).

137 Council Decision (CFSP) 2016/993 of 20 June 2016 amending Decision (CFSP) 2015/778 on a European Union military operation in the Southern Central Mediterranean (EUNAVFOR MED operation SOPHIA), [2016] OJ L162/18; On the arms embargo, see UNSC Res 2292 (14 June 2016) UN Doc S/RES/2292. A further extension has been agreed until 31 December 2018, see EC Press Release 494/17 (25 July 2017) <http://www.consilium.europa.eu/en/press/pressreleases/2017/07/25-eunavformed-sophia-mandate-extended/>.

${ }^{138}$ EEAS, EUNAVFOR MED Op Sophia - Six Monthly Report 1 January-31 October 2016, Council doc 14978/16 (30 November 2016) 14-15 (emphasis added) ('Operation Sophia Report 2016').
} 
to prevent migrants from leaving the country ${ }^{139}$ _ ignoring the rights to leave and to asylum recognized in international and EU law. ${ }^{140}$ Crucially, this implies that '[i]f migrant boats intercepted in Libyan waters by Libyan vessels are taken back to Libyan shores ... the EU non-refoulement obligations would not be triggered' (at least not directly or immediately). ${ }^{141}$ The goal is for pre-emptive take-backs to ultimately replace SAR, ${ }^{142}$ shifting the responsibility for refugee and migrant flows to Libya. ${ }^{143}$

There is a similar approach adopted in the Aegean, where NATO launched an operation similar to EUNAVFOR Med in February 2016 along Turkish shores. Just like the Frontex missions and Operation Sophia, its goal is 'to [contribute to] the international efforts to stem the illegal trafficking and illegal migration in the Aegean', in the words of NATO Secretary General. ${ }^{144}$ The operation is formally only 'tasked to conduct reconnaissance, monitoring and surveillance of illegal crossings in the Aegean' ${ }^{145}$ It does not have a SAR or border control competence. However, when encountered with distress situations, it has been agreed that assets will proceed to the rescue of those concerned, returning them directly to Turkey ${ }^{146}$ _ whatever the impact on fundamental freedoms. The conclusion of the EU-Turkey deal in March 2016, whereby Turkey must impede boat migrants' exit and accept the readmission of all those arriving irregularly on EU soil in exchange for financial and other support, facilitates this course. ${ }^{147}$ Returns to Turkey, through disembarkations performed upon rescue or interdiction by NATO assets, are being conducted in disregard of non-refoulement, ${ }^{148}$ which should determine the choice of 'place of safety', according to IMO Guidelines and human rights law, as further detailed

139 Council of the European Union, 'Malta Declaration by the Members of the European Council on the External Aspects of Migration: Addressing the Central Mediterranean Route' (Press Release 43/17, 3 February 2017) ('Malta Declaration') para 6(j).

${ }^{140}$ For a detailed elaboration, see Moreno-Lax, Accessing Asylum (n 17), chs 8 and 9.

141 J Sunderland, 'Why Cooperating with Libya on Migration Could Damage the EU's Standing' (Human Rights Watch, 7 November 2016) < https://www.hrw.org/news/2016/11/07/whycooperating-libya-migration-could-damage-eus-standing >. cf Moreno-Lax and Giuffré (n 22).

142 Denouncing a 'take back' episode, see 'Sea-Watch Demands Independent Investigation of the Illegal Return of an Overcrowded Wooden Boat', Sea Watch Press Release (11 May 2017) <https:// sea-watch.org/en/pm-sea-watch-demands-independent-investigation-of-the-illegal-return-of-anovercrowded-wooden-boat/>.

143 On the characterization of 'take backs' or 'pull backs', see N Markard, 'The Right to Leave by Sea: Legal Limits on EU Migration Control by Third Countries' (2016) 27 EJIL 591. Generally, on responsibility for rescue at sea, see E Papastavridis, 'Rescuing Migrants at Sea and the Law of State Responsibility' in Gammeltoft-Hansen and Vedsted-Hansen (n 61) ch 7.

144 'NATO Defence Ministers Agree on NATO Support to Assist with the Refugee and Migrant Crisis' (NATO, 11 February 2016) <http://www.nato.int/cps/en/natohq/news_127981.htm>.

145 ibid.

146 See A Rettman, 'Nato to Take Migrants back to Turkey, If Rescued' (EUObserver, 23 February 2016) <https://euobserver.com/foreign/132418> reporting declarations by NATO Secretary General to the European Parliament.

147 European Commission, Seventh Report on the Progress made in the implementation of the EU-Turkey Statement, COM(2017) 470.

148 B Frelick, 'NATO Enters the Migration Control Business' (EUObserver, 18 February 2016) $<$ https://euobserver.com/opinion/132309>; On the precarious situation of refugees and migrants in 
below. ${ }^{149}$ The full implications of SAR obligations are being discounted, if not instrumentalized for security purposes.

The situation has apparently been 'normalised' after the launch of Operation Sea Guardian in November 2016, ${ }^{150}$ and the EU-NATO Warsaw Declaration, ${ }^{151}$ where Member States seem to have endorsed NATO's perspective and decided to join efforts. NATO warships are thus now helping the EU's cause to stem the flow of mostly Syrian asylum seekers across the Eastern Mediterranean. According to the Greek Defence Minister, '[t]he prevention of refugee flows [sic] with NATO ships will continue as long as there are prospective illegal migrants or refugees [sic] on the other side of the Aegean'. ${ }^{152}$ And so, arguably, with NATO's involvement in migration control, 'a dangerous shift toward militarization of a humanitarian crisis' has been consolidated in the Mediterranean Sea. ${ }^{153}$

\section{B. Disembarkation, 'Place of Safety', and Non-Refoulement}

One of the key issues that arises during SAR activities involving boat migrants is the selection of an appropriate location where rescuees can be disembarked. This issue was partially addressed in the 2004 SOLAS amendments and associated IMO Guidelines, but significant ambiguities remain. ${ }^{154}$

The EU has sought to tackle this in the 2014 Maritime Surveillance Regulation (MSR) by articulating modalities for disembarkation following the rescue or interception of vessels in the context of Frontex-coordinated operations. These must be agreed in advance and inserted in the operational plan of the relevant deployment. As a rule, where interdiction occurs in the territorial waters or contiguous zone, disembarkation should normally take place in the coastal Member State. ${ }^{155}$ But, if rescue or interception occurs on the high seas, the preferred place of disembarkation is 'in the third country from which the vessel is assumed to have departed'. ${ }^{156}$ Where disembarkation follows a SAR incident, it is for the relevant Rescue

Turkey, see Amnesty International, A Blueprint for Despair: Human Rights Impact of the EUTurkey Deal (2017) <https:/www.amnesty.org/en/documents/eur25/5664/2017/en/>.

149 IMO, Res MSC.167(78), [2.1.2], [6.17].

150 'NATO Launches New Operation Sea Guardian' (NATO, 9 November 2016) <http://www. nato.int/cps/en/natohq/news_137427.htm>.

151 'Warsaw Summit Communiqué Issued by the Heads of State and Government participating in the meeting of the North Atlantic Council in Warsaw 8-9 July 2016' (NATO, 9 July 2016) <http://www. nato.int/cps/en/natohq/official_texts_133169.htm?mc_cid=f8343b1adb\&mc_eid=bf01703a94>.

152 'NATO's Aegean Patrols to Continue' (Ekathimerini, 6 February 2017) <http://www. ekathimerini.com/216266/article/ekathimerini/news/natos-aegean-patrols-to-continue>.

${ }^{153}$ See comments from Human Rights Watch: 'Nato to Launch New Mediterranean Mission' (EU Observer, 10 July 2016) <https://euobserver.com/tickers/134276?mc_cid=f8343b1adb\&mc_ eid $=$ bf01703a94 $>$.

154 See ( $\mathrm{n} 46$ ) and related discussion.

${ }^{155}$ MSR art 10(1)(a). Note, however, that this is 'without prejudice' to ordering the vessel concerned to alter its course or escorting it outside the territorial sea or contiguous zone of the Member State concerned, pursuant to MSR art 6(2)(b).

156 MSR art 10(1)(b) (emphasis added). 
Coordination Centre to identify an appropriate 'place of safety'-excluding ports in non-participating Member States, unless they consent. ${ }^{157}$

The MSR - based on the IMO Guidelines but codifying them into hard law for EU law purposes - provides that a 'place of safety' shall be a 'location where rescue operations are considered to terminate and where the survivors' safety of life is not threatened'; a place 'where their basic human needs can be met'. Moreover, in accordance with human rights principles, it shall also be a location where protection and compliance with the principle of nonrefoulement is guaranteed. ${ }^{158}$ Unlike the duty to rescue, non-refoulement 'shall apply to all measures taken by Member States or the Agency', making the EU Coastguard explicitly bound by attendant obligations. ${ }^{159}$

As a result, the MSR contemplates that interdicted or rescued persons cannot be 'disembarked in', nor can they be 'forced to enter, conducted to or otherwise handed over to the authorities of', a country where there are serious risks of being subjected to persecution or inhuman or degrading treatment or punishment, whether directly or by onward removal to another country. ${ }^{160}$ Therefore, when considering disembarkation in a third country, the prevailing situation there must be taken into account. Information derived from a wide range of sources is essential. It is, however, unclear what the significance of 'the existence of agreements and projects on migration and asylum carried out in accordance with Union law and through Union funds' may be in this assessment, but it is one of the factors contemplated in the MSR. ${ }^{161}$ Also, although the identification and assessment of personal identity and circumstances have to be undertaken before removal, and persons concerned informed of their destination so they can oppose it on refoulement grounds, there is no provision for procedural safeguards, remedies, or judicial oversight to guarantee compliance with the principle in practice. ${ }^{162}$ This contravenes human rights standards, as per Hirsi and related case law. ${ }^{163}$

As advanced as the MSR provisions may be in certain respects, particularly as they represent a regional arrangement followed by 28 Member States, they suffer from an additional key limitation. They apply only to EU Coastguardcoordinated operations and thus leave untouched any arrangements regarding unilateral action or collaborative conduct undertaken outside the Frontex framework. Arguably, these exclusions encompass the EUNAVFOR Med Operation Sophia and actions taken under the auspices of NATO, leaving an important gap in effective protection, considering developments on the ground - including non-assistance and abandonment at sea ${ }^{164}$ — and the fact

157 MSR art 10(1)(c).

158 MSR art 2(12) and recital 12.

159 MSR art 4(7) and recital 10; EBCGR art 34(1) (emphasis added).

160 MSR art 4(1); EBCGR art 34(2). $\quad 161$ MSR art 4(2). 162 MSR art 4(3).

163 See, extensively, Moreno-Lax, Accessing Asylum (n 17) chs 6, 8 and 10.

164 See eg S Osborne, 'Horrific Phone Calls Reveal How Italian Coast Guard Let Dozens of Refugees Drown' The Independent (Online, 8 May 2017) <http://www.independent.co.uk/news/ 
that it remains disputed whether EU non-refoulement provisions have an extraterritorial reach beyond Member States' domain. ${ }^{165}$

There is currently no comparable regional agreement between Australia and its neighbours on the issue of disembarkation. As the MV Pinar and MV Tampa incidents demonstrate (see Part I), governments may be reluctant to permit the disembarkation of rescued asylum seekers into their territory and may attempt to deflect responsibility to other jurisdictions. This can create uncertainty and discourage commercial vessels from participating in SAR activities. It also prevents Australian Government vessels from carrying out SAR in Indonesian waters, as it could result in Australia having to assume responsibility for disembarkation. The importance of dealing with the disembarkation issue in the Asia-Pacific region was raised at the Sixth Ministerial Conference of the Bali Process on People Smuggling, Trafficking in Persons and related Transnational Crime held in March 2016. The Ministerial Declaration adopted at the conference recognizes the importance of coordinating procedures for rescue at sea and calls on participating governments to "work to identify more predictable disembarkation options'. ${ }^{166}$ But, to date, there have been no concrete proposals.

Australia has also had cause to contemplate disembarkation at a 'place of safety' and the extent to which this duty is affected by considerations of nonrefoulement. Regardless of whether the purported basis of an interception is SAR or security-related maritime interdiction, under Australian law, once a vessel is under the control of Australian authorities, the Australian Government has a responsibility to deliver the rescuees to a "place of safety'. ${ }^{167}$ Recent actions by Australian authorities appear to flout this requirement. While the lack of transparency around push-back operations (elaborated upon in the next section) makes a definitive assessment difficult, it is hard to conceive how leaving migrant vessels on the edge of Indonesian territorial waters could be viewed as delivery to a 'place of safety'. ${ }^{168}$ This is regardless of whether they are aboard their original vessel or have been transferred to lifeboats or other vessels provided by the Australian authorities. In both instances, the migrants are left to navigate a potentially perilous sea

world/europe/italian-navy-lets-refugees-drown-migrants-crisis-asylum-seekers-mediterranean-seaa7724156.html >.

165 C-638/16 $X$ and $X$ [2017] ECLI:EU:C:2017:173. cf V Moreno-Lax, Asylum Visas as an Obligation under EU law: Xv Belgium, Parts I and II, Migration Law Blog (16 and 21 February $2017)<$ http://eumigrationlawblog.eu/asylum-visas-as-an-obligation-under-eu-law-case-ppu-c63816-x-x-v-etat-belge/>.

166 'Bali Declaration on People Smuggling, Trafficking in Persons and Related Transnational Crime, Sixth Ministerial Conference of the Bali Process on People Smuggling, Trafficking in Persons and related Transnational Crime' (The Bali Process, 23 March 2016) <http://www. baliprocess.net/> [5].

${ }_{167}$ See National Search and Rescue Manual (n 93) para 6.1.1 and MPA section 74.

168 D Ghezelbash, Refuge Lost: Asylum Law in an Interconnected World (Cambridge University Press, forthcoming); cf N Klein, 'Australia's Push Back the Boats Policy under International Law' (2014) 15 MelbJIL 414, 426-7. 
voyage on their own. Similar actions under Operation Relex, providing a point of comparison, reportedly resulted in loss of life. ${ }^{169}$

These actions have been possible because of the lack of a clear definition of 'a place of safety' in Australian law. Neither the National Search and Rescue Manual or the Maritime Powers Act refer to the specific circumstances of asylum seekers and the need to protect against refoulement. In fact, following the passage of Migration and Maritime Powers Legislation Amendment (Resolving the Asylum Legacy Caseload) Act 2014 (Cth) ('Legacy Caseload Act)', consideration of such factors is explicitly prohibited in certain contexts. ${ }^{170}$ The amendments stipulate that when exercising maritime powers, an authorizing officer is not required to consider Australia's international obligations or the international obligations or domestic law of another country. ${ }^{171}$ Additionally, the amendments stipulate that authorization of maritime powers under the Act is not invalid even if inconsistent with Australia's international obligations. ${ }^{172}$ As such, there are no clear legal safeguards in place to ensure that Australia does not breach its nonrefoulement obligations by returning a person to a place where they face persecution contrary to the Refugee Convention, or to a situation where they are in danger of death, torture, or other unlawful mistreatment. ${ }^{173}$

However, these amendments do not necessarily preclude an expansive interpretation of a 'place of safety' under the Maritime Powers Act ('MPA'). The Legacy Caseload Act did not remove the requirement that a 'maritime officer must not place ... a person in a place, unless the officer is satisfied, on reasonable grounds, that it is safe for the person to be in that place'. ${ }^{174}$ The breadth of this requirement was addressed by a number of the justices of the Australian High Court in $C P C F v M I B P$. The case was brought on behalf of a Tamil plaintiff who was part of a group of 157 Sri Lankan asylum seekers intercepted and detained at sea by Australian authorities for almost one month. The challenge was dismissed, with a majority of the court finding the detention lawful under the Maritime Powers Act. The facts before the court did not give rise to any issues of refoulement (the asylum seekers had eventually been transferred to the Australian run Regional Processing Centre in Nauru). A number of the justices nevertheless indicated a willingness to interpret the meaning of a 'place of safety' broadly, as encompassing similar protections to the non-refoulement obligations of the Refugee Convention

169 C Stewart, 'Law of the Sea versus the Dictates of Canberra' Weekend Australian (10 March 2012) 19.

${ }^{170}$ Legacy Caseload Act sch 1; this act was passed in response to the $C P C F$ litigation examined below at ( $\mathrm{n}$ 175) and accompanying text. ${ }^{171}$ MPA section 22A(1)(a).

172 ibid $22 \mathrm{~A}(1)(\mathrm{c})$.

173 Refugee Convention, art 33; ICCPR, art 7; CAT, art 3. For a comprehensive analysis, see K Wouters, International Legal Standards for the Protection from Refoulement (Intersentia 2009). More recently, see C Costello and M Foster, 'Non-refoulement as Custom and Jus Cogens? Putting the Prohibition to the Test' (2015) 46 NYIL 273.

174 MPA section 74 . 
and other human rights instruments. ${ }^{175}$ For example, Hayne and Bell JJ stated, in terms similar to French $\mathrm{CJ}$, that:

[t]he reference in s 74 to a person being 'safe' in a place must be read as meaning
safe from risk of physical harm. A decision-maker who considers whether he or
she is satisfied, on reasonable grounds, that it is safe for a person to be in a place
must ask and answer a different question from that inferentially imposed by the
Refugees Convention. But there is a very considerable factual overlap between
the two inquiries. Many who fear persecution for a Convention reason fear for
their personal safety in their country of nationality. ${ }^{176}$

Kiefel $\mathrm{J}$ took a different approach, finding that section 74 only required that a point of disembarkation for a person is 'in its immediate physical aspects ... safe'. ${ }^{177}$ It did not require that a maritime officer be satisfied that the place is one in which the person will not face a real risk of harm more generally. ${ }^{178}$ As the matter was left unresolved, this is an issue that will no doubt be explored further in future litigation.

As things stand, there is currently no guarantee under Australian law of a reading of 'delivery to a place of safety' in line with the prohibition of refoulement, while in Europe procedural safeguards are, in turn, insufficient to secure such result in practice. This arguably renders maritime operations in both regions legally unsustainable as currently practised.

\section{Lack of Transparency and Accountability}

The securitization of SAR and its conflation with/subordination to securityrelated interdiction activities in Europe and Australia have resulted in a lack a transparency and accountability. This development, while unwelcome, is unsurprising because security operations are routinely shrouded in secrecy to avoid public scrutiny and the potential compromising of 'successful' operations.

In Australia, as noted above, Operation Sovereign Borders operates under a veil of silence. The government has sought to justify its decision not to comment on 'on-water operational matters' on the ground of national security and because such disclosure would benefit 'the people smugglers and their business model'. ${ }^{179}$ The secrecy has been extended to SAR operations. Since the commencement of the operation, AMSA has stopped posting shipping broadcasts requesting assistance on its website. ${ }^{180}$ Ships involved in SAR activities receive direct communication from the Rescue Coordination Centre, but details of the activities are not released to the public. This secrecy

\footnotetext{
175 CPCF v Minister for Immigration and Border Protection (2015) 255 CLR 514.

176 ibid [109], [12]. 177 ibid [296]. 178 ibid.

179 P Chambers, 'The Embrace of Border Security: Maritime Jurisdiction, National Sovereignty, and the Geopolitics of Operation Sovereign Borders' (2015) 20 Geopolitics 404, 427.

180 A Lloyd, Senate Budget Estimates Briefing Note on AMSA's Role in Search and Rescue Incidents, released in response to an FOI request from H Degan $<$ https://www.righttoknow.org. $\mathrm{au} /$ request/operation_sovereign_borders>.
} 
makes it difficult to assess the extent to which Australian authorities are conforming to their obligations under the SAR regime, as well as under the Refugee Convention and human rights instruments.

Similar secrecy applies in recent EU interdiction activities carried out behind the shield of 'EU security'. ${ }^{181}$ A recent application for disclosure of the Operational Plan and Evaluation Report of Frontex-led Operation Hera in the period 2012-2015 in Western Africa and around the Canary Islands, submitted in 2016 by the European Centre for Constitutional and Human Rights (ECCHR), provides a telling example. Frontex purported to justify its extensive redaction of the Operational Plan by reference to 'public security' considerations, including a list of potential fundamental rights violations within Frontex activities. ${ }^{182}$ The argument is particularly inappropriate because it impedes any meaningful accountability of the Agency.

In Europe, channels of democratic oversight exist, but remain weak. ${ }^{183}$ Since 2011, Frontex has been obliged to formulate and implement a (non-legally binding) Fundamental Rights Strategy to ensure that its operations fully respect fundamental rights. ${ }^{184}$ The European Parliament has exerted limited control through budgetary procedures. ${ }^{185}$ Moreover, the EBCG Regulation now provides that the EU Coastguard shall be accountable to the Parliament (art 7) and that, prior to appointment, the Executive Director of the Coastguard shall make a statement before the European Parliament, if requested, and 'report to it regularly' thereafter (art 68), which may improve the current opacity.

Nevertheless, for the time being, the information released to the public on Frontex or EU Coastguard activities tends to be superficial and incomplete. The structure of general reports was revised in 2008 and the level of detail noticeably decreased. ${ }^{186}$ According to the Agency, the purpose of general

181 On the notion of 'EU security', see European Commission, The European Agenda on Security $\operatorname{COM}(2015) 185$.

182 V Wriedt and D Reinhardt (ECCHR), 'Opaque and Unaccountable: Frontex Operation Hera' (Statewatch, February 2017) <http://www.statewatch.org/analyses/no-307-frontex-operation-hera. pdf $>$.

${ }^{183}$ For similar analyses, see S Léonard, 'The Creation of FRONTEX and the Politics of Institutionalisation in the EU External Borders Policy' (2009) 5 Journal of Contemporary European Research 371; S Léonard, 'EU Border Security and Migration into the European Union: Frontex and Securitisation through Practices' (2010) 19 European Security 231; and R Mungianu, 'Frontex: Towards a Common Policy on External Border Control' (2013) EJML 359.

184 EBCGR art 34(1); Frontex, Fundamental Rights Strategy <http://frontex.europa.eu/assets/ Publications/General/Frontex_Fundamental_Rights_Strategy.pdf $>$.

185 See J Pollak and P Slominski, 'Experimentalist but not Accountable Governance? The Role of Frontex in Managing the EU's External Borders' (2009) 32 WEurPol 904; According to Frontex Regulation (n 30), art 25(2), 'the European Parliament or the Council may invite [her] to report on the carrying out of his/her tasks' (emphasis added), but this has been interpreted as not entailing a legally-binding obligation to appear in person for the purpose.

186 See Frontex, General Report 2008, $10<\mathrm{http}$ ///frontex.europa.eu/about-frontex/governancedocuments/2008>; General Report $2009<\mathrm{http}$ ://frontex.europa.eu/about-frontex/governancedocuments/2009>. 
reports is actually to provide 'a broad overview of activities ... and highlight individual operational ... successes', ${ }^{187}$ which leaves limited space for genuine external inspection. What is more, under the present Coastguard Regulation, 'communication activities shall not be detrimental to [Coastguard] tasks', which provides a basis for the Agency's discretionary release of information, including selective redaction of documentation on vague security grounds, as the ECCHR case demonstrates. ${ }^{188}$

It is the linkage between SAR with issues of migration control and border security, coupled with the absence of independent, comprehensive monitoring mechanisms ${ }^{189}$ that have allowed both the EU and Australia to diminish transparency of strategic decisions and on-water operations. The resulting reduction of the quality and opportunity for democratic oversight can thus be connected with an underlying securitization paradigm.

\section{Cooperation and Commodification}

States are reluctant to engage in SAR operations involving boat migrants because of the responsibilities that may arise in relation to determining asylum applications, as exemplified by the second of our two rescue tales in Part I, the MV Pinar incident. This concern is compounded by ambiguity surrounding key elements of the international SAR regime-in particular the meaning of 'distress', 'place of safety', and the selection of a point of disembarkation. The importance of this issue is widely acknowledged, but attempts to address it have fallen short to date. ${ }^{190}$ The 2004 SOLAS amendments require State parties to cooperate to ensure that masters are relieved of their obligations to assist 'with minimum further deviation from the ship's intended voyage', but they do not go as far as mandating specific modalities for disembarkation. ${ }^{191}$ EU norms are more detailed and prescriptive, but only apply to EU Coastguard-led operations, as pointed out above. Their full development in terms of identification and referral protocols in line with SAR standards, international human rights and refugee law has not been achieved.

\footnotetext{
187 Frontex, General Report 2010, <http://frontex.europa.eu/about-frontex/governancedocuments/2010> (emphasis added). $\quad{ }^{188}$ EBCGR art 8(3) cf art 74.

189 An initiative has been launched, drawing on the premises of the 'comprehensive approach' put forward in Moreno-Lax and Papastavridis (n 33), for the establishment of a Search and Rescue Observatory for the Mediterranean (SAROBMED), through the joint collaboration of SAR NGOs, academics, and other stakeholders, to collate and publicly disseminate data on SAR incidents and interdiction-related events, with a view to combating the lack of transparency and accountability resulting from the securitized approach of the EU <http://www.law.qmul.ac.uk/events/items/ death-at-sea-and-the-securitisation-of-search-and-rescue.html > and < https://sea-watch.org/en/ report-of-death-at-sea-and-the-securitisation-of-search-and-rescue-on-29-09-2017-in-london/>.

190 For an elaboration regarding the Mediterranean basin, see J Coppens and E Somers, 'Towards New Rules on Disembarkation of Persons Rescued at Sea?' (2010) 25 IJMCL 377; See also J Coppens, 'Disembarkation of Migrants Rescued at Sea' (De Lloyd 29 December 2010) at 15 (Pt I), and 3 January 2011, at 55 (Pt II).

191 See (n 49-52) and related discussion.
} 
In the absence of more detailed international rules, such as new IMO Guidelines or a further reform of the maritime conventions, it is up to individual States to enter into agreements with neighbouring countries as to how best to deal with this issue. Hitherto, such cooperation has not been forthcoming. While shiprider and similar agreements have been concluded for law-enforcement purposes, ${ }^{192}$ States appear to be unwilling to participate in any arrangement that would result in them assuming (greater or any) responsibilities for rescued boat migrants. Cooperation is viewed as a zerosum game, resulting in some States reducing their obligations at the cost of others taking on a greater burden. ${ }^{193}$

Cooperation around law enforcement and securitization of borders may also be characterized as a zero-sum game. When States undertake actively to prevent the passage of boat migrants to another jurisdiction, they are in effect shifting the flow (and related responsibility) of those persons. However, States value such cooperation to the extent that they are willing to provide substantial payment or other inducements to partners. ${ }^{194}$ The reality is that saving lives does not have the same priority.

One can observe cooperation becoming commodified in this way in the Mediterranean, ${ }^{195}$ where the replacement of SAR with law enforcement and militarized border control efforts has become widespread. Some speak of a 'world of cooperative deterrence'196 or the 'rise of consensual containment' in this regard, ${ }^{197}$ conceptualizing an ever-expanding trend that infringes the most basic rights of boat migrants.

The EU tends to avoid unilateral action. Rather, the organization — via the EU Coastguard, EUNAVFOR Med, and individual Member States - trades in trust, exchanging funds and assets for pull-backs and border-enforcement capacity of transit countries with cooperation in the containment of flows and the fight

192 See Papastavridis (n 49) 221, defining shiprider agreements as: 'bilateral treaties ... where each party is required to designate law enforcement officials to embark on the vessels of other parties in order to facilitate ... the exercise of relevant national law enforcement powers within zones of jurisdiction of the former party'. See also Guilfoyle (n 91) ch 8.

193 On the lack of sufficient investment in SAR and post-SAR action, including poor implementation of internal relocation plans for refugees, see Guild, Costello and Moreno-Lax (n 118).

194 Note eg the promise by the EU to pay Turkey several billion Euros in the form of a Refugee Facility as part of their so-called 'deal' (n 20).

195 For a detailed account, see R Andersson, Illegality, Inc.: Clandestine Migration and the Business of Bordering Europe (University of California Press 2014). See also T GammeltoftHansen and $\mathrm{N}$ Nyberg Sorensen, The Migration Industry: The Commercialization of International Migration (Routledge 2013).

${ }^{196}$ T Gammelhoft-Hansen and JC Hathaway, 'Non-Refoulement in a World of Cooperative Deterrence' (2015) 53 ColumJTransnatlL 235. See further T Gammeltoft-Hansen, 'International Refugee Law and Refugee Policy: The Case of Deterrence Policies' (2014) 27 JRS 574; and T Gammeltoft-Hansen and N Feith Tan, 'Beyond the Deterrence Paradigm in Global Refugee Policy’ (2016) 39 SuffolkTransnatlLRev 637.

197 Moreno-Lax and Giuffré (n 22). 
against unauthorized migration. ${ }^{198}$ The implementation of the EU-Turkey Statement, the Memorandum of Understanding with Libya, and the related partnership with NATO, analysed above, demonstrates this strategic, selective approach to multilateral trust and collaboration with neighbours in the region. ${ }^{199}$ The key drawback of this instrumentalization is its impact on SAR and human rights protection, which have been fundamentally distorted and made into a tool in the arsenal of the 'war on smugglers' across the Mediterranean. 200

Australia has achieved mixed results in enlisting the cooperation of neighbouring States in its interdiction and push-back operations. Sri Lanka has successfully been engaged to collaborate in joint interceptions and takeback procedures, as well as to disrupt refugee departures before they occur. Australia has provided equipment to Sri Lanka to assist them in carrying out these tasks, including two Bay Class patrol vessels gifted to the Sri Lankan navy. ${ }^{201}$ Cooperation has also been forthcoming from Vietnam, which has accepted returns of its nationals intercepted at sea en route to Australia. ${ }^{202}$ Australia's relationship with Indonesia is somewhat more complicated. ${ }^{203}$ While the two nations have a long history of cooperating around border control issues, particularly through their role as joint chairs of the Bali Process on People Smuggling, Trafficking in Persons and Related Transnational Crime, Australia's securitized approach to boat migration has eroded trust and placed significant strain on the relationship. ${ }^{204}$ So much so that Australian authorities unilaterally return boats to the edge of Indonesian territorial waters without consultation with, or approval from, the Indonesian Government. ${ }^{205}$ Relations have been further damaged by revelations that Australian Navy Customs vessels had repeatedly ventured into Indonesian

\footnotetext{
198 For recent analyses, in this line, of the new EU Partnership Framework, COM(2016) 385, see Moreno-Lax, 'The Migration Partnership Framework and the EU-Turkey Deal: Lessons for the Global Compact on Migration Process?' in T Gammeltoft-Hansen et al., What Is a Compact? Raoul Wallenberg Institute Working Paper (10 October 2017) $27<$ http://rwi.lu.se/app/uploads/ 2017/10/RWI_What-is-a-compact-test_101017.pdf>; and C Bauloz, The EU Migration Partnership Framework: an External Solution to the Crisis? EU Migration Law Blog (31 January 2017) <http://eumigrationlawblog.eu/the-eu-migration-partnership-framework-anexternal-solution-to-the-crisis/>.

199 Other examples include ad hoc agreements to allow EU Member States, particularly Spain, to intercept vessels in the territorial waters of North and West African nations such as Senegal and Mauritania: Papastavridis (n 49) 287; Guilfoyle (n 91) 218-19.

200 'Europe is Declaring War on Smugglers' (n 130).

201 A Hirsh, 'The Borders Beyond the Border: Australia's Extraterritorial Migration Controls' (2017) 36 Refugee Survey Quarterly 48, 75.

${ }_{202}$ See, for example, L Cochrane, 'Vietnamese Asylum Seeker Returned by Australia Says "A Bullet Would be Better"' ABC News (Online, 23 February 2017) <www.abc.net.au/news/2017-0221/vietnam-asylum-seeker-returned-by-australia-speaks-of-beatings/8288226>.

${ }^{203}$ For a detailed analysis of the shifting dynamics of this relationship, see S Kneebone, 'Australia as a Powerbroker on Refugee Protection in Southeast Asia: The Relationship with Indonesia' (2017) 33 Refuge 29. ${ }^{205}$ See, eg, M Bachelard, 'Australian Navy Turns Back Asylum Seeker Boat to Indonesia after Loading Three Extra People' Sydney Morning Herald (Online, 6 May 2017)<http://www.smh.com.
} 
waters without authorization as part of patrols relating to Operation Sovereign Borders, ${ }^{206}$ as well as allegations in 2015 that cash payments had been made by Australian authorities to induce Indonesian crew members of a migrant vessel to return to Indonesia. ${ }^{207}$ In both instances, the actions were viewed by Indonesia as a significant breach of its sovereignty and territorial integrity. ${ }^{208}$ This growing distrust has serious flow-on effects for the operation of SAR in the region, and makes reaching agreement on key issues like modalities of disembarkation all the more difficult.

Australia has had success in commodifying and outsourcing other elements of its international responsibilities, particularly where it has been unable to successfully push back asylum seekers at sea. Under Australian law, persons that attempt to reach Australia by boat are barred from applying for asylum or ever settling in Australia. ${ }^{209}$ They are instead transferred to facilities in Manus Island, PNG or Nauru, to have their protection claims assessed under the domestic laws of those countries. ${ }^{210}$ Cooperation from PNG and Nauru was secured through substantial cash inducements delivered through Australia's aid programme, and payments covering the costs of building and running the detention centres where rescued/intercepted asylum seekers are placed on arrival. ${ }^{211}$ The facility on Manus Island was decommissioned on 31 st October 2017, ${ }^{212}$ following a decision of the Supreme Court of PNG declaring the detention of asylum seekers illegal. ${ }^{213}$ But there are currently

au/federal-politics/political-news/australian-navy-turns-back-asylum-seeker-boat-to-indonesiaafter-loading-three-extra-people-20140505-zr55k.html>; see also Kneebone (n 203).

206 Senate Foreign Affairs, Defence and Trade References Committee, Parliament of Australia, Report: Breaches of Indonesian Territorial Waters (2014).

207 Senate Legal and Constitutional Affairs References Committee, Parliament of Australia, Report: Payment of Cash or Other Inducements by the Commonwealth of Australia in Exchange for the Turn Back of Asylum Seeker Boats (2015).

${ }^{208}$ G Roberts, "Indonesia Believes Australia Made "Illicit Payments" to Crew of People Smuggling Boat, Foreign Ministry Says’ $A B C$ News (Online, 20 June 2015) <http://www.abc.net. au/news/2015-06-19/indonesia-believes-'illicit-payments'-made-to-people-smugglers/6559676>; J Garnaut and M Bachelard, 'Joko Widodo's Blunt Warning to Prime Minister Tony Abbott' Sydney Morning Herald (Online, 18 October 2014) < http://www.smh.com.au/federal-politics/politicalnews/joko-widodos-blunt-warning-to-prime-minister-tony-abbott-20141017-11719i.html>.

209 Migration Act 1958 (Cth) section 46A; Under section 46A(2) the Minister has discretion to exempt an applicant in the public interest.

${ }^{210}$ Memorandum of Understanding between the Republic of Nauru and the Commonwealth of Australia, relating to the Transfer to and Assessment of Persons in Nauru, and Related Issues, signed 3 August 2013; Regional Resettlement Arrangement between Australia and Papua New Guinea, signed 19 July 2013.

211 B Opeskin and D Ghezelbash, 'Australian Refugee Policy and Its Impacts on Pacific Island Countries’ (2016) Journal of Pacific Studies 73.

${ }^{212}$ M Koziol and J Massola, 'Manus Refugees Given Ultimatum as Turnbull Government Comes under Pressure' The Age (Online, 30 August 2017) < http://www.theage.com.au/federalpolitics/political-news/manus-refugees-given-final-ultimatum-as-turnbull-government-comesunder-pressure-20170830-gy715b.html>.

213 Namah v Pato [2016] PGSC 13; SC1497 (26 April 2016). For analysis, see A Dastyari and M O'Sullivan, 'Not for Export: The Failure of Australia's Extraterritorial Processing Regime in PNG and the Decision of the PNG Supreme Court in Namah (2016)' (2017) 42 MonLR 308. 
no plans to amend or rescind the arrangement with Nauru. Cambodia has also been recruited to resettle a handful of the refugees processed on Nauru. Only six have so far volunteered for the programme, and, of these, four decided instead to return to their home countries, citing unbearable living conditions. ${ }^{214}$ This has come at the cost of approximately AUD\$55 million to the Australian government in additional aid and direct payment for resettlement services. ${ }^{215}$

As in the case of the EU, the intention of these arrangements is to 'outsource' Australia's international obligations with respect to refugees and migrants to poorer neighbours in the region. ${ }^{216}$ Both Australia and the EU seem to be under the impression that cooperation in this guise releases them of any international responsibility. Yet, in most cases, the States concerned will still be responsible under general customary law, ${ }^{217}$ either through exercising effective control (such as Australia's direct involvement in offshore processing) or through complicity, direction, and/or control of internationally wrongful acts committed by the third country (as in the case of the EU and Italy's support to pull-backs by Libya). ${ }^{218}$ What neither region appears to realize is that, pursuant to the pacta sunt servanda principle, 'every treaty in force [eg the Refugee Convention or instruments of human rights law] is binding upon the parties to it and must be performed by them in good faith'. ${ }^{219}$ Once concluded, it may be denounced - if the text so allows - but cannot be 'contracted out' via subsequent (if cooperative) arrangements. ${ }^{220}$ In those circumstances, the very wording of the Vienna Convention on the Law of Treaties indicates that responsibility 'may arise for a State from the conclusion or application of a [subsequent] treaty [however named] ${ }^{221}$ the provisions of which are incompatible with its obligations towards another State under another [prior] treaty'.222 Otherwise, the opposite would mean that 'the

214 M Gleeson, In Focus: Resettlement of Refugees from Nauru to Cambodia (21November 2016) UNSW Kaldor Centre for International Refugee Law <http://www.kaldorcentre.unsw.edu. $\mathrm{au} /$ news/focus-resettlement-refugees-nauru-cambodia>.

${ }^{215}$ M Gleeson, 'FactCheck Q\&A: How Much Was Spent on the Cambodia Refugee Deal and How Many Were Settled?' The Conversation (Online, 21 November 2016)<https:// theconversation.com/factcheck-qanda-how-much-was-spent-on-the-cambodia-refugee-deal-andhow-many-were-settled-68807>.

${ }^{216}$ Whether 'safe third country' transfers are in line with international law should, however, not be taken for granted. See, in this regard, V Moreno-Lax, 'The Legality of the "Safe Third Country" Notion Contested: Insights from the Law of Treaties' in GS Goodwin-Gill and P Weckel (eds), Migration \& Refugee Protection in the 21st Century: Legal Aspects - The Hague Academy of International Law Centre for Research (Martinus Nijhoff 2015) 665.

217 ILC Articles on the Responsibility of States for Internationally Wrongful Acts ('ASR'), [2001] YILC Vol II (Pt 2), Annex to UNGA Res 56/83, 12 December 2001 (A/56/49(Vol. I)/Corr.4).

218 ASR, arts 16, 17, and 47. See further, Moreno-Lax and Giuffré (n 22).

219 VCLT, art 26 (emphasis added).

${ }^{220}$ GS Goodwin-Gill, 'The Extraterritorial Processing of Claims to Asylum or Protection: The Legal Responsibilities of States and International Organisations' (2007) 9 UTSLRev 26, 34.

221 We embrace the material understanding of a treaty as codified in art 2(1)(a) VCLT as: 'an international agreement concluded between States in written form and governed by international law, whether embodied in a single instrument or in two or more related instruments and whatever its particular designation' (emphasis added).

222 VCLT, art 30(5). 
guarantees of [eg refugee and human rights conventions] could be limited or excluded at will thereby depriving [them] of [their] peremptory character and ... practical and effective nature ....'223

\section{E. Criminalization}

The void left by official authorities, in terms of SAR coverage in the Mediterranean, has been filled by civil society organizations undertaking private rescues. Especially since the outbreak of the 'crisis' in 2015, several NGOs have been formed with the purpose of locating and assisting migrant boats in the Central Mediterranean and the Aegean Sea. ${ }^{224}$ Their intervention has very much changed the landscape, to the extent that they have been recorded to perform up to half of the total rescues undertaken. ${ }^{225}$ This, in turn, has been perceived to create a 'call effect' or 'pull factor', facilitating the deeds of human traffickers and migrant smugglers. ${ }^{226}$ Although Frontex has denied direct accusations, ${ }^{227}$ these have been reported by the press ${ }^{228}$ and have translated, at least on two occasions, on the pressing of charges against NGOs. ${ }^{22}$ Proemaid, a group of Spanish fire-fighters operating in Lesbos, has been accused of 'attempted' human trafficking under Greek law, and there is an open case against the German Jugend Rettet in Italy. ${ }^{230}$

Although the European Commission has denied any need to revise the Facilitators Directive to unambiguously decriminalize humanitarian

223 ECtHR, Bosphorus v. Ireland, App 45036/98 (30 June 2005) para 154 (emphasis added).

224 The Righteous of the Mediterranean campaign, promoting the nomination of NGOs and other worthy persons for the 2018 Nobel Peace Prize, has counted 'more than 60 subjects' <http://www. nobel-righteous-mediterraneansea.info $>$.

225 Operation Sophia Report 2016 (n 138) 3, 7-8.

226 Demonstrating the baselessness of this assertion, see E Steinhilper and R Gruijters, 'Border Deaths in the Mediterranean: What We Can Learn from the Latest Data' Border Criminologies Blog (8 March 2017) <https://www.law.ox.ac.uk/research-subject-groups/centre-criminology/ centreborder-criminologies/blog/2017/03/border-deaths $>$.

227 Letter by F Leggeri, Frontex Executive Director, to MEP Miguel Urban Crespo of 21 June 2017, Ref. CAB/EWMO/10434/2017 (on file).

${ }_{228}$ See 'EU Border Force Flags Concerns over Charities' Interaction with Migrant Smugglers' Financial Times (Online, 16 December 2016). See also reaction by MSF, 'Bounties not Bodies: Smugglers Profit from Sea Rescues Though No Clear Alternative Available’ MSF Analysis (23 December 2016) <http://msf-analysis.org/bounties-not-bodies-smugglers-profit-sea-rescuesthough-no-clear-alternative-available/>.

${ }^{229}$ Denouncing 'fabricated accusations', see 'Imaginary Criminals: Sea-Watch considers legal steps against attorney Zuccaro’ Sea Watch Press Release (24 April 2017) <https://sea-watch.org/ en/imaginary-criminals-sea-watch-considers-legal-steps-against-attorney-zuccaro/>.

230 A Edmond, 'Spanish Fire-Fighters Who Saved Lives at Sea Must Not Be Criminalised' Institute of Race Relations News (18 May 2017) <http://www.irr.org.uk/news/spanish-firefighters-who-saved-lives-at-sea-must-not-be-criminalised/>; and AL Camilli, 'All the Accusations against the NGO Jugend Rettet' Mediterranean Hope (8 August 2017) <http://www. mediterraneanhope.com/rassegna-stampa/all-the-accusations-against-the-ngo-jugend-rettet-1950>. 
assistance under EU law, ${ }^{231}$ there is a solid consensus in the literature 232 that the EU instrument is not in full alignment with the Smuggling Protocol, ${ }^{233}$ as it omits that for the perpetration of the crime of facilitation of irregular entry into a Member State there needs to be an economic gain ${ }^{234}$ - on top of a mens rea or criminal intent element and a link to organized transborder mafias. ${ }^{235}$ The travaux préparatoires make clear that the reference in the definition of migrant smuggling in Article 3 of the Protocol to 'a financial or other material benefit' was included precisely 'to emphasize that the intention was to include the activities of organized criminal groups acting for profit, but to exclude the activities of those who provided support to migrants for humanitarian reasons'. ${ }^{236}$ The Protocol's aim was not to punish NGOs.

By contrast with the EU situation, to date, there have been no NGO groups involved in active search and rescue missions targeting asylum seekers and migrants off Australia's coast. If such operations were to take place, the crew of the NGO vessels may be liable for prosecution under Australia's strict anti-people smuggling laws. First introduced in 1999, the anti-people smuggling provisions have progressively broadened in the intervening years. ${ }^{237} \mathrm{As}$ in the EU, there is no requirement of 'a financial or other material benefit'. ${ }^{238}$ All that is required is that a person 'organises or facilitates' the entry (or proposed entry) of a migrant who has no right to enter Australia. ${ }^{239}$ Where there are more than five migrants involved, this constitutes an aggravated offence with a penalty of up to 20 years imprisonment. ${ }^{240}$ Reforms introduced in 2011 make it clear that it is

231 European Commission, Refit Evaluation of the EU legal framework against facilitation of unauthorized entry, transit and residence: the Facilitators Package (Directive 2002/90/EC and Framework Decision 2002/946/JHA), SWD(2017) 117.

${ }^{232}$ See eg S Bellezza and T Calandrino, Criminalization of Flight and Escape Aid BorderlineEurope (March 2017) <https://crimig.files.wordpress.com/2017/02/kidem-doc-final-2-5-17.pdf>; and C Heller and L Pezzani, Blaming the Rescuers, Forensic Oceanography (2017) <https:// blamingtherescuers.org/report/>.

233 Protocol Against the Smuggling of Migrants by Land, Sea and Air, supplementing the United Nations Convention against Transnational Organized Crime, supplementing the United Nations Convention against Transnational Crime [2001] 40 ILM 384.

234 See eg S Carrera et al., Fit for Purpose? The Facilitation Directive and the Criminalisation of Humanitarian Assistance to Irregular Migrants, European Parliament Study PE 536.490 (2016).

${ }_{235}$ This results from a systematic reading of the Smuggling Protocol in line with the UNTOC, UN Convention against Transnational Organized Crime [2000] 2225 UNTS 209.

236 See UNODC, Model Law against the Smuggling of Migrants (October 2010) 27, referring to the Interpretative notes, A/55/383/Add.1, para 88, and Travaux Préparatoires, at $469<\mathrm{https}$ ://www.unodc. org/documents/human-trafficking/Model_Law_Smuggling_of_Migrants_10-52715_Ebook.pdf $>$. The Travaux are compiled in an e-book <https://www.unodc.org/pdf/ctoccop_2006/04-60074_ebook-e. pdf $>$.

${ }^{237}$ See Border Protection Legislation Amendment Act 1999 (Cth); Anti-People Smuggling and Other Measures Act 2010 (Cth) and Deterring People Smuggling Act 2011 (Cth). For analysis of these reforms, see A Schloenhardt and C Craig, 'Prosecutions of People Smugglers in Australia 2011-14' (2016) 38 SydLR 49, 52-4.

238 Migration Act 1958 (Cth) sections 233A, 233B, 233C and 233D; Criminal Code Act 1995 (Cth) sections 73.1, 73,2, 73.3, 73.3A.

240 Migration Act 1958 (Cth) section 233C; Criminal Code Act 1995 (Cth) 73.3. 
immaterial whether Australia owes, or may owe, the migrants protection obligations under the Refugee Convention and Protocol, or other human rights instruments. ${ }^{241}$ Persons who donate money to NGOs involved in search and rescue of asylum seekers and migrants at sea may also face criminal charges for the offence of providing material support or resources to a person or organization involved in people smuggling. ${ }^{242}$ It may be possible, however, for those involved in humanitarian rescue to rely on the defence of 'sudden and extraordinary emergency', which is included in the Criminal Code Act 1995 (Cth). ${ }^{243}$ This defence will be successful where the accused can show that they were obliged to commit an offence by reason of some extraordinary emergency. It is arguable that rendering assistance to persons in distress at sea would meet this requirement. ${ }^{244}$ However, hitherto, this defence remains largely untested in Australian courts. ${ }^{245}$

The criminalization of people smuggling, and in particular the enactment of broad offences that go well beyond what is authorized and required under the Smuggling Protocol, are yet another manifestation of the securitization of SAR in the EU and Australia.

\section{CONCLUSION}

The fundamental humanitarian purpose of SAR is under threat because of the securitization and, increasingly, the militarization and criminalization of boat migration. The practice of the European Coastguard and individual EU Member States, as well as Australia, demonstrates that the line between SAR and security-related interdiction has been increasingly blurred and manipulated. The Australian regime ostensibly intends to identify whether a vessel is one requiring a SAR response or is an instance of unlawful entry, and different agencies are mobilized accordingly. However, if an Australian asset is deployed for SAR, the operation falls under the Maritime Powers Act and secrecy requirements follow. In the EU, the Coastguard is primarily focused on border-enforcement operations, which have been increasingly securitized as a response to people smuggling and human trafficking. This characterization has been reinforced by Security Council Resolution 2240 (2015) and formal collaboration with EUNAVFOR Med Operation Sophia and NATO Sea Guardian patrols. In these examples, the SAR regime is either relegated or merged into a law-enforcement response to people smuggling. Instead, the critical task of identifying a vessel in distress should be the catalyst for

241 Deterring People Smuggling Act 2011 (Cth)

242 Migration Act 1958 (Cth) section 233D; Criminal Code Act 1995 (Cth) section 73.3A.

243 Criminal Code Act 1995 (Cth) section 10.3.

244 This position would be consistent with the supplementary and interpretive material to the Smuggling Protocol which makes it clear that those engaging in humanitarian assistance should be exempt from criminal liability: see (n 235) and accompanying text.

245 Schloenhardt and Craig (n 237). 
determining whether the response should be directed through the SAR regime or whether the vessel should be subjected to an interdiction measure for migration control purposes.

Securitization is also eroding the spirit of cooperation that is so essential to the effectiveness of the SAR regime. Rescues at sea often involve authorities from multiple jurisdictions. It is common for a rescue to be carried out by a merchant vessel flagged in State A, coordinated by authorities from State B, and end with disembarkation in State C. Any perception that one or more of the parties may not carry out their respective obligations in good faith is a disincentive for the other parties involved. Securitization of SAR in one jurisdiction can also place pressure on other jurisdictions to follow suit. This is the result of a perception that a robust SAR apparatus may act as a 'pull factor' for boat migrants, despite evidence denying such effect. ${ }^{246}$ Hence, there is a risk of a 'race to the bottom' as States prioritize security over saving lives at sea in a bid to divert irregular migrant flows to other jurisdictions. ${ }^{247}$ This situation underscores the need to recover the humanitarian essence of SAR and shed the regime of its securitized and militarized connotations. SAR should be understood as an end in itself, not as a means to prevent irregular migration at the service of anti-smuggling strategies.

At least since the Corfu Channel case, it has been known that 'elementary considerations of humanity' still adhere in situations of high security concern, particularly where human lives are at stake. ${ }^{248}$ In adopting a securitization frame for responding to boat migration, States still retain core responsibilities in how they carry out law enforcement operations. In particular, the International Tribunal for the Law of the Sea has recognized that considerations of humanity apply in the law of the sea, and even law enforcement operations must not travel beyond what is a reasonable and proportionate use of force. ${ }^{249}$ These standards must be borne in mind in the type of actions taken in response to boat migration. In the treatment of boat migrants, States must recall that they 'are required to fulfil their obligations under international law, in particular human rights law, and that considerations of due process of law must be applied in all circumstances'.250

\footnotetext{
246 See Steinhilper and Gruijters (n 226); Davies and Neslen (n 83) and (n 226) and accompanying discussion.

247 For an examination of how competitive tendencies influence the development of restrictive asylum policies, see Ghezelbash (n 168).

248 Corfu Channel Case (UK v Albania) (Merits) [1949] ICJ Rep 4, 22.

249 The M/V 'SAIGA' (No. 2) Case (Saint Vincent and the Grenadines $v$ Guinea) (Judgment of 1 July 1999) ITLOS Reports 1999 [155]; see also The Arctic Sunrise Arbitration (Netherlands $v$ Russia) (Merits), PCA Case No 2014-02 (UNCLOS Annex VII Arb Trib, 14 August 2015), [197]-[198] (where the Tribunal found that international human rights law can be considered when determining what is a reasonable and proportionate use of force). See Guilfoyle (n 91) 271-2 for an analysis of the interpretation of 'disproportionate force' in this context.

250 The M/V 'Louisa' Case (Saint Vincent and the Grenadines $v$ Kingdom of Spain) (Judgment of 28 May 2013) ITLOS Reports 2013 [155].
} 
It is important to remember that the SAR regime is just one of a number of overlapping international legal regimes governing the power of States to deal with boat migrants at sea. Refugee law, international human rights law, the law of the sea, and the human smuggling and trafficking frameworks are all relevant in this regard. States often deal with these regimes in a fragmented manner, ${ }^{251}$ cherry picking provisions that allow them to justify a securitized approach to protect State interests. ${ }^{252}$ Further research on how these regimes intersect, and how they can be integrated in a mutually reinforcing way, may provide the key to recovering the humanitarian dimension of SAR. ${ }^{253}$ In such a conception, the obligations of humanity extended to those in peril at sea would be blind as to their identity as lone yachtsmen from the developed world or 'huddled masses yearning to breathe free'.254

251 See eg Klein (n 6) 787; Moreno-Lax (n 6). 221.

J Coppens, 'Interception of Migrant Boats at Sea' in Moreno-Lax and Papastavridis (n 33)

253 Proposing a methodology of 'cumulative standards' to reconcile human rights, humanitarian law, and refugee law standards that could serve as a template, see V Moreno-Lax 'Systematising Systemic Integration: "War Refugees", Regime Relations, and a Proposal for a Cumulative Approach to International Commitments' (2014) 12 JICJ 907.

254 E Lazarus, The New Colossus (1883). 